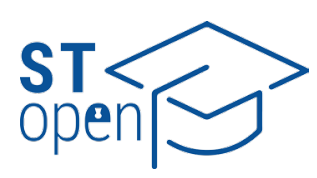

(c) 2020 The Author(s)

\title{
The Breivik case and the comparative issues of criminal (in)sanity
}

\section{Mislav Burazer* (1)}

University of Split, Faculty of Law, Split, Croatia

*Current affiliation: University of Zagreb, Faculty of Law, Zagreb, Croatia
Correspondence to:

Mislav Burazer

Pujanke 59, 21000 Split, Croatia

mislav.burazer92@gmail.com

Cite as:

Burazer M. The Breivik case and the compar ative issues of criminal (in)sanity. ST-OPEN. 2020; 1: e2020.1919.5.
In the summer of 2011, Anders Behring Breivik committed a terrorist attack in Norway in which 77 people were killed, and at least 319 more were injured. This paper analyses several aspects of the deadliest attack on European soil since World War II, primarily the psychological background of this crime and its legal implications. The paper consists of three sections. The first section presents the comparative and legal basics of criminal insanity that is necessary in order to understand the sections that follow. The second section deals with the perpetrator's psychological profile and the great debate that had ensued due to the contradicting reports of the Norwegian experts. The last section of the paper summarises the essence of the previous two sections while presenting a comparative procedural analysis of hypothetical trials in select jurisdictions. This paper is based on a comparative analysis of legal norms that aims to highlight the high complexity of the issue. The Breivik case has been selected as an ideal example because, on the one hand, it has created a number of contradicting opinions within its domestic legal system while, on the other hand, its universal nature makes it suitable for a more complex comparative analysis.

\section{Introduction}

The issue of criminal insanity presents one of the oldest issues in criminal law. Insanity based on psychiatric disturbances is generally viewed as the basis to exclude the perpetrator from criminal liability. Historically, it dates back to ancient Greek and Roman law and has been relatively clearly formulated in the Byzantine Empire during the reign of Emperor Justinian (Walker, 1985). Today, the concept of insanity is an integral part of all penal systems, though certain differences - whether minor or major - exist in regulating this highly important legal institution. 
This paper is inspired by the tragic terrorist attack that struck Norway in 2011, as well as its consequences. Anders Behring Breivik's murderous rampage was the most lethal attack in Norway since World War II, while the mass murder on Utøya represents the most lethal mass attack by an individual using a firearm anywhere in the world. His case received strong media attention and incited fear all over Europe, especially due to it not seeming like the act of a lone madman or maniac, but rather like a series of actions meticulously planned by a highly composed individual. This is why there were great disagreements in Norway regarding the state of mind of Anders Behring Breivik, leading to a significant amount of discord between Norwegian legal experts.

These disagreements are analysed in the paper by using a comparative approach focused on the criminal-psychological factor that represents the foundation of the legal issues in Breivik's case.

This approach has two main goals. On the one hand, the goal is to illustrate how the Breivik case is both intriguing and complex at the same time, or rather how many and which problems it would cause or might have caused had it happened in some other part of the world. The amorality of Breivik's acts is universal, but different national regulations pose an interesting question regarding societal and governmental reactions to that form of amorality. The second goal is purely comparative - to present the reactions of different judicial systems in resolving the same legal issue. Breivik's case is quite suitable for this because it is unique, interesting, and controversial. Also, it is one of the rare modern cases in which there was a situation with two contradicting opinions regarding the perpetrator's state of mind, while at the same time having practically the whole case documentation publicly available for analysis.

However, this paper exceeds the scope of the original case and transforms into a legal-psychological study, aiming to highlight the underlying problems of this case, but also their universal nature.

The underlying hypothesis the paper is based on is that the Breivik case represents a universal problem but without a universal reaction. Regrettably, the Breivik case is no longer a locally and causally isolated incident never to be feared again. It is a potential issue that could appear anytime and anywhere in the world, even if similar incidents that have happened before 2011 - or between 2011 and the time of writing of this paper - are excluded. Therefore, the analysis presented in this paper will show that a hypothetical Breivik is possible anytime, anywhere, and that countries are not unequivocally prepared to react to that potential issue.

\section{Methods}

This analysis was primarily based on the Norwegian courts' and medias' publicly available data, as well as on the publicly available legislation of the selected countries, with the other sources, such as news articles, books and interpretations listed separately. In regards to the selection of legal systems that have been analysed, the basic criterium was to provide a representation of conceptually different systems, to illustrate different theoretical and 
practical approaches to criminal insanity. Thus, the systems that were selected might, in an ideological sense, be described as conservative, liberal and mixed - reflecting the ideas on the purpose of criminal proceedings in each of those systems. In the structural sense, they may also be divided into groups such as civil law, common law and Sharia-based systems - which in turn reflects the different concepts of this issue in the scope of legal theory.

The analysis began by addressing the issues found in substantive criminal law because they were of the utmost importance for the complete understanding of the rest of the paper. All other relevant questions - such as the mental state and capacity to stand trial were observed either in the light of criminal insanity (psychological profile) or in the light of the consequences of deeming the perpetrator (in)sane (the issue of whether the perpetrator is capable of participating in the proceedings applies only to those perpetrators that are deemed sane since the insane ones are not tried in the same way).

In the second section of the paper, which documents the process of Breivik's psychological assessment in Norway, along with the issues and controversies that arose during the same process, we have provided a critical evaluation of certain aspects of his profile by using the general methodology of criminal profiling that is, despite mainly being applied to unknown perpetrators, also applicable to known perpetrators, and is often used for those purposes as well (Burazer, 2019).

Comparative analysis was used in the final section as well, although this time in relation to the procedural rules. We have analysed the relevant regulations pertaining to substantive and procedural criminal law, but also the regulations of supplementary laws that deal with the (criminally) insane. All the texts are publicly available, whether as originals or as translations, and the usage of any applicable interpretations has been marked where cited.

\section{The Breivik case}

On July 22, 2011 between 15:25 and 18:34 local time, Anders Behring Breivik committed two coordinated terrorist attacks in Norway. A car bomb exploded in central Oslo at 15:25, killing 8 and wounding at least 209 individuals. Barely two hours later, at 17:21 on the small island of Utøya, that same person attacked the meeting of the Norway Labour Party, killing 69 and wounding at least 110 people. The attack lasted until the attacker was arrested at 18:34 (Johannessen, 2012). Anders Behring Breivik, the perpetrator of these heinous terrorist attacks, made his place in history as one of the most infamous murderers of the modern era.

At the moment of committing the crime, Breivik was 32 years old and hailed from a family of divorced parents. He had been arrested and reported to social services several times during his youth over spraying graffiti in the Oslo area (Meldalen et al., 2012). His application for obligatory military service was rejected by the Norwegian Defence Security Department with the explanation "unfit for military service" (Landsend et al., 2011). With a critical view towards leftist ideologies, the young Breivik joined the right-wing Progressive Party, which was based on strong anti-immigration policies; he left the party in 2006, after 
four years of membership. According to his own statements, Breivik had begun to construct his 9-year plan, which was supposed to culminate in the terrorist attacks on July 22, 2011 (as it really did), as early as 2002.

About half an hour before the bomb was about to detonate in Oslo, Breivik published an online manifesto titled "2083 - A European Declaration of Independence" (Norwegian: “2083 - En europeisk uavhengighetserklcering”), where he elaborated his militarist, anti-immigration, xenophobic, Islamophobic and anti-feminist views. He later stated to a Norwegian court that popularising this manifesto was the only motive for the horrendous attacks (Kremer, Stigset, \& Treloar, 2011).

Breivik was arrested soon after the attack, with his trial beginning on April 16, 2012; he was imprisoned until an evaluation could be made regarding his sanity and the ability to stand trial. The final statements were made on June 22, the same year, and on August 24, 2012, the Oslo District Court (Norwegian: Oslo tingrett) sentenced Breivik to 21 years of preventive detention, which is the highest possible sentence prescribed in Norwegian law; Breivik had been refusing to acknowledge the court's jurisdiction in this case, so he declined to file an appeal (Tretvoll, 2012). Following his sentencing, he was transferred from prison unit in Bærum to a high-security prison (Norwegian: særlig høy sikkerhet, SHS) in Skien, where he is currently serving his sentence. It is interesting to note that between 2002 (when the SHS penal system was first introduced) and 2016, only ten or eleven individuals in all of Norway have been incarcerated under such strict conditions, with Breivik's sentence being the longest of them all (Wergeland, Zondag, Jørstad, Moland, \& Andersen, 2016).

This brief overview of the facts of the case is meant to serve only as a portrait of Breivik's character and the case itself, since a detailed analysis of his biography and all the facts concerning the attack, no matter how interesting, would far exceed the scope of this paper.

In the end, along with the goals outlined in the introduction, this study will also serve as an insight into the psychology of Anders Behring Breivik, which is as terrifying as it is fascinating. Since this is a relatively new case and because no study like this has been performed in this field yet, the author is convinced that he is going to provide additional insights and answer additional questions, as well as strengthen the foundation for further discourse concerning a problem of vital importance in modern criminal law - the psychology of the perpetrators of severe crimes.

\section{Issue no. 1: (In)sanity}

Before the proceedings in front of the Oslo District Court began, Anders Behring Breivik had been held in the prison unit in Bærum, pending expert evaluations regarding his mental state not just in tempore criminis, but also post criminis. In practice, that meant that the courts, before the proceedings actually started, were required to determine both whether Breivik was sane at the time the crime was committed, and whether he was capable of standing trial. This is why we start off with the theoretical basis necessary for understanding the remaining sections of the paper, that are going to give a more detailed look into practical implications of criminal insanity within the context of the Breivik case. 
In the modern civil law theory of criminal law, which generally recognizes four elements of a crime - the act, its substance, unlawfulness, and culpability - sanity is the first element of culpability, usually being defined as "being capable of guilt” (Novoselec \& Bojanić, 2013; Horvatić, Derenčinović, \& Cvitanović, 2017). In comparison, common law recognizes only two elements of a crime - actus reus and mens rea. Since sanity is generally presumed, the lawmakers usually consider the negative definition of sanity, i.e., the idea of insanity as the incapability of guilt. Sanity is generally divided into two elements - the intellectual and voluntary - that must both exist for insanity to be excluded. The intellectual element, i.e., the capability to understand, means that the perpetrator of a crime understands that their actions represent an illegal act that is defined as being criminal (punishable) and understand the consequences of their actions (Novoselec \& Bojanić, 2013). The voluntary element, i.e., the possibility of controlling one's voluntary actions, means that the perpetrator is able to control their behaviour, or rather, to direct their will towards desired goals (Novoselec \& Bojanić, 2013). Consequently, to be deemed sane, a perpetrator must fully appreciate that they had committed a crime, as well as the consequences of their actions (the intellectual element), and have had complete control over their actions (the voluntary element). If either of these two elements is missing, the perpetrator will be declared criminally insane and, generally speaking, will not be subject to regular punishment.

The grounds for criminal insanity are as different as the theories regarding its causes (Horvatić et al., 2017); however, they generally amount to (severe) psychiatric disturbances that inhibit the intellectual and/or voluntary element. Since Norwegian law is the most relevant for this case, we will firstly present the regulation of criminal insanity in the Norwegian system, followed by a few comparative examples that display certain differences in how criminal insanity is understood.

\section{Norway}

The Norwegian Penal Code (Norwegian: Lov om straff/Straffeloven) has been in force since October 1, 2015, when it replaced the General Civil Penal Code, which had been considered one of the most revolutionary penal codes in the world when it entered into force back in 1902. Though the General Civil Penal Code had been in force during both of Breivik's crimes and his trial, there have been no substantial changes regarding the content dealing with criminal insanity, except for some numeration and structural changes (the old law regulated criminal insanity in its Articles §44-46). The current Norwegian Penal Code defines sanity in $\$ 20$ (Norwegian: Tilregnelighet), where it states that the perpetrator of a crime must be sane in order to be punished (Straffeloven, 2005). The text of §20 continues listing the grounds of criminal insanity, stating that a person shall not be considered sane if at the moment the crime was committed they were (1) less than 15 years old; (2) psychotic; (3) severely mentally disabled; or (4) suffering from severe impairment of consciousness. The final section of $\$ 20$ explicitly states that the aforementioned impairment of consciousness will not be considered as a basis for criminal insanity if it is a result of self-intoxication by alcohol consumption, which is a classic example of self-induced insanity (Novoselec \& Bojanić, 2013). If we disregard the first basis (which is an example of the non-application of criminal legislation to persons based on their age), the grounds listed under (2)-(4) show that the basic starting point for understanding criminal insanity is 
the perpetrator's mental state at the moment the crime was committed, i.e., the "minimal mental capacity" (Norwegian: psykisk minstekapasitet), as it is called in Norwegian legal theory (Boucht, 2015). In order to gain a practical understanding of how the Norwegian law perceives these medical terms, it is necessary to analyse each of the three psychological grounds from $\$ 20$ of the Norwegian Penal Code.

Regarding psychosis, i.e., a psychotic mental state, professor Johan Boucht states that it is defined as the "ability to realistically interpret the relations with the outside world" (Boucht, 2015). So, the causes of psychosis can be different mental disorders that disrupt a proper perception of reality, and they can be determined using either the medical, the psychological or the mixed principle. Norwegian law relies strictly on the medical principle, where a psychiatric diagnosis is a necessary prerequisite to determine psychosis. Other systems, such as the Finnish one, use a mixed approach based on both medicine and psychology (Boucht, 2015). The Norwegian legal expert Johannes Andenæs explains that a psychotic state is, interestingly enough, determined "cleanly" (Norwegian: det rene), without the need to determine a causal link between the psychotic state and the crime itself (Boucht, 2015). The second basis pertains to a high degree of mental disability, i.e., those individuals whose intelligence quotient (IQ) has been measured at around 55. The only possible method of establishing this is by performing intelligence testing and referring to the scientifically accepted degrees of mental retardation. However, it must be emphasized that only individuals with a severe form of mental retardation may be considered insane (making the severity of mental retardation an essential element of this criterium), while milder forms of mental retardation may only affect some subjective elements of a specific crime (Boucht, 2015). Severe impairments of consciousness are divided into absolute (coma), that always lead to the exclusion of sanity, and relative (hypnosis, somnambulism, some states involving high fever, epilepsy), in which sanity is evaluated on a case-by-case basis (Boucht, 2015). Norwegian law even puts certain conditions, that, in other systems (such as Sweden, Finland, even Croatia), are studied as part of the theory of the criminal act, or more specifically, as part of the interpretation of the act's negative functions, in this category (Boucht, 2015; Novoselec \& Bojanić, 2013).

As we are going to see in the following sections, Norwegian law does not significantly differ from other civil law systems in regards to definitions and criteria of criminal insanity. The issue of age, which is not relevant within the scope of this paper, often fluctuates between being among the grounds for the non-application of the criminal legislature in some countries and being treated as a basis for criminal insanity in other systems, while the psychological grounds are mostly identical to other civil law systems, regardless of the differences in the way the norms are formulated in the acts. Though the issue of (in)sanity opens up more interesting questions (such as diminished and substantially diminished responsibility, the burden of proof, expert witnesses, self-induced insanity, the influence of the cause on the commission of the crime itself), it is not necessary, within the context of this paper, to examine each of them in detail. These individual issues will be addressed in later sections of the paper where necessary. 


\section{Croatia}

Croatian law, with which we start our comparative analysis, regulates criminal insanity (mental incapacity) in Article 24 of the Criminal Code (Croatian: Kazneni zakon, or KZ), which, in paragraph 2, lists the bio-psychological grounds of insanity - a mental illness, a temporary mental disorder, an insufficient mental development, or some other severe mental disorder (Novoselec \& Bojanić, 2013). Both theory and practice refer to the first of these as psychosis (Horvatić et al., 2017), and it completely overlaps with the first basis (psychotic state) found in Norwegian law. Although temporary mental disorders encompass the more severe (though temporary) impairments of consciousness, it should be emphasized that in Croatian law, this aspect is interpreted somewhat differently, and may include some other mental states (for example a state of fright, an acute stress reaction, "short-circuiting”), which would not be considered as grounds for criminal insanity in Norwegian law (Novoselec \& Bojanić, 2013; Horvatić et al., 2017). The third Croatian basis (an insufficient mental development) also matches the Norwegian criterium. However, Croatian law has an additional basis, which might be referred to as a "general clause", and includes specific mental disorders that do not fit into any of the other categories but may still significantly affect the perpetrator's mental state. This often includes personality disorders, impulse control disorders, neuroses and post-traumatic stress disorder (PTSD). However, other disorders may be included too since the list is not considered final (Novoselec \& Bojanić, 2013). Generally speaking, Croatian law requires that the causal link between one of the grounds of insanity and the act performed in tempore criminis has to be established, i.e., it is necessary to determine whether the crime was truly a consequence of one of the aforementioned grounds. In addition, the Criminal Code currently in force states that mentaly incapable individuals are not considered guilty under Croatian law (which is a significant difference, because in some other jurisdictions they are considered guilty, but cannot be punished). This means that no sentence can be handed out to them, but certain security measures still might, and they might fall under the scope of the Act on the Protection of Persons with Mental Disorders (PPMD) (Kazneni zakon, 2011).

\section{France}

French law is of particular interest due to the fact that the current Code pénal (C.P.), in force since 1992, does not contain any definition of (in)sanity but has rather defined it through court decisions as "acting with both knowledge and will” (Pradel, 2014). The term imputabilité (which might better be translated as "accountability" rather than "sanity") consists of three elements - the ability to discern (French: le discernement), the freedom of action (French: la liberté), and awareness of the act being illegal (French: la connaissance). Only the first element is relevant for this paper, while the other elements are related to other aspects of substantive criminal law, which is a result of the systemic differences and approaches of French law, compared to the rest of continental Europe. French law recognizes only two grounds of criminal insanity - psychiatric or neuropsychiatric disorders (French: le trouble psychique ou neuropsychique), and the so-called states similar to psychiatric or neuropsychiatric disorders (French: les états voisins du trouble psychique et neuropsychique) - that must be present at the moment the crime was committed, and that must, by their very nature, be severe (Code pénal, 1992). The first group encompasses a 
plethora of psychiatric disturbances that would otherwise be separated into special categories (such as psychoses, schizophrenia, insufficient degree of mental development). The second group includes disorders of voluntary control, somnambulism and voluntary intoxication (Pradel, 2014). According to French law, a criminally insane person still remains a perpetrator, but will not be held responsible for the committed act. However, if they continue to pose a danger to themselves and others, they can be institutionalized according to the regulations set in the Code of Public Health (Pradel, 2014). As we can see, though similar in principle and doctrine, and being part of the civil law system, French law is still reasonably specific in comparison, and its structure and the breakdown of criminal insanity are difficult to compare to the two aforementioned systems.

\section{Russia}

The Russian legal system treats criminal insanity (Russian: невменяемость, пеvтеnyayemost) almost identically as Croatian law, despite a somewhat different nomotechnical approach. According to the Criminal Code of the Russian Federation (Russian: Уголовный кодекс Российской Федерации Ugolovnyy kodeks Rossiyskoy Federatsii), the grounds for criminal insanity are chronic or temporary mental derangement, mental deficiency (an insufficient degree of spiritual development) or some other mental condition (Ugolovnyy kodeks Rossiyskoy Federatsii, 1996). Due to the existence of a similar general clause, Russian law is somewhat closer to the Croatian system than the Norwegian one in respect to criminal insanity (though the actual differences are minimal). However, it differs from both systems by possessing a specific exemption in its Article 21, paragraph 2 of the Criminal Code of the Russian Federation based on which a criminally insane person may be subjected to compulsory medical measures, as defined in chapter 15 of that same Code (Ugolovnyy kodeks Rossiyskoy Federatsii, 1996).

\section{Common law (United Kingdom, United States of America)}

The term common law primarily refers to the legal systems of the United Kingdom and the United States of America, but also to those of the majority of former British colonies that have adopted the system throughout the years of colonial influence and are still using it to this day. The general idea behind the common law's perception of criminal insanity is that it primarily represents a procedural element, not a substantive one; thus, criminal insanity is studied in the scope of what is called the insanity defence. Despite each of the individual systems - meaning, primarily, English and Welsh, Northern Irish, Scots, and American law - presenting a set of very interesting specific attributes, their differences and rules are so numerous that analysis would far exceed the scope of this study. Thus, only the most basic common elements will be presented in this section (Burazer, 2016).

The insanity defence (or defense) is an official defence in common law jurisdictions, according to which the defendant claims that he was insane at the time the crime was committed. That defence exists in every common law jurisdiction, though its origins may differ significantly, as it is briefly going to be elaborated below. While the United States of America, England and Wales (the latter two are considered to be a single unit in the legal sense) have a strong procedural perception of criminal insanity - it is a purely procedural 
aspect whose proof is based on one of several expert tests such as the M'Naghten test, the Irresistible Impulse Test, the Model Penal Code test or the Durham test, aimed at determining the "degree of preservation" of intellectual and voluntary elements - the Northern Irish and, especially, Scots law present a strong influence of civil law and, despite the fact that criminal insanity is still interpreted within the scope of their criminal procedure, include legal definitions that are much closer to the civil law concept of criminal insanity as an element of substantive, rather than procedural law (Burazer, 2016). Sanity is always presumed in common law, thus placing the burden of proof on the defendant, making it necessary for him to satisfy various standards of proof in front of the jury (usually preponderance of the evidence, but other standards may arise, such as clear and convincing proof, or even proof beyond a reasonable doubt). As far as direct consequences of criminal insanity go, they may vary between jurisdictions, meaning that variants exist in which the accused may receive a sentence of "not guilty by reason of insanity", but may also be proclaimed "guilty but insane". An acquittal is also a possibility, though more commonly encountered in Britain than in the United States. Meanwhile, some jurisdictions (e.g., Northern Ireland) have special laws governing the procedure against the criminally insane (Burazer, 2016).

\section{Turkey}

Despite the predominantly civil law influences and a secular Penal Code, Turkish law is interesting because of the increased Islamization that is slowly being implemented by President Recep Tayyip Erdoğan (Akyol, 2016). The Turkish Penal Code (Turkish: Türk Ceza Kanunu) regulates criminal insanity (Turkish: akll hastalığl) in Article 32, where it is defined that a person who has not understood the legal meaning and consequences of their actions, or was not in control of their actions due to a mental disorder, shall not be punished, but that such persons may be subjected to specific security measures applicable towards the criminally insane, as they are outlined in Article 57 of the Penal Code (Türk Ceza Kanunu, 2004). The general definition of criminal insanity in Turkish law remains a mirror image of civil law influences, except for the fact that Turkish law recognizes only a single basis for criminal insanity - a mental disorder (Göktürk, Özgenç, \& Üzülmez, 2012). The individual may be either partially or completely insane, and it is important that criminal insanity, especially in cases of partial insanity, is always evaluated in the context of the actual relation between the disorder and the crime. For example, a kleptomaniac will always be considered insane when committing theft, but not when they, for example, commit murder since murder is in no way related to the kleptomaniac's compulsive need for taking others' possessions (Göktürk et al., 2012). The Turkish lawmaker has been very specific in his phrasing of the norm, stressing the importance of the intellectual and voluntary elements of insanity, meaning that a person shall not be considered criminally insane if they merely suffered from a mental disorder, but without the impairment of the intellectual and/or voluntary elements (e.g., personality disorder). 


\section{Sharia Law (Iran)}

The Islamic Republic of Iran does not have a codified criminal code in the same sense that European countries have. Although Iranian law is far from precedent-based (such as common law), the fact that Sharia law depends on theological dogmas has resulted in Iran lacking any sort of codified criminal code until 1982 (Burki, 2013). When they finally opted to codify their regulations, it was mostly done by codifying the pre-existing rules of Sharia law (Abrahamian, 1999), with very little secular influences. The initial codifications have been collected into what is the contemporary Islamic Penal Code, which is divided into five books and represents a complex codification of the penal rules found in Sharia law (Islamic Penal Code, 2012). The official pages of the United Nations High Commissioner for Refugees (UNHCR) state that a new Islamic Penal Code was passed in 2012, entering into force sometime in 2018 (UNHCR, 2019). Iranian penal regulations are extremely strict; however, following the 1982 codification, significant changes were made to the traditional freedoms enjoyed by the acting judge. On the one hand, their authority became more limited (for example, each death sentence issued must now be confirmed by the Supreme Court); on the other hand, the Penal Code was formulated in such a manner that certain offences, in what is supposed to be the special part of the Penal Code, are defined very loosely, thereby providing judges with a great degree of arbitrary freedom in setting standards of evidence, sentencing and similar elements of criminal law. Though all the regulations are, at least in principle, still compliant with Sharia law, the Iranian system is nevertheless unique, because of the numerous regulations contradicting the Sharia law that have been passed since 1982 (Abrahamian, 2008). Criminal insanity exists in the Islamic Penal Code and is regulated in the first book (Preliminary Regulations), in Articles 149 and 150.

The former states that a person deprived of their sense of discernment or the ability to control their will due to a mental disorder will be declared criminally insane and, thus, cannot be criminally liable (Islamic Penal Code, 2012). This, seemingly straightforward, definition of criminal insanity is taken from civil law systems and feels almost like an intruder within the context of the otherwise strict Sharia code. However, the regulation set in Article 150 illustrates the severity of Sharia law even when criminal insanity is concerned. Namely, according to the aforementioned Article, if the perpetrator of a crime was insane at the time the crime was committed or became insane afterwards, but before the criminal proceedings began, the Iranian public prosecutor may issue an order for them to be sent to a psychiatric institution until their condition improves, provided that he deems the perpetrator to be a threat to the community - as determined by a psychiatric expert (Islamic Penal Code, 2012). The perpetrator and his family can appeal the decision before a judge, who will then evaluate the prosecutor's decision in a non-contentious proceeding; the judge shall re-evaluate the decision and the expert opinion and will then either confirm or revoke the prosecutor's decision (Islamic Penal Code, 2012). It is interesting to note that the judge's decision cannot be appealed directly, though it can be re-evaluated at a later stage if any of the concerned parties deem the perpetrator to no longer be a threat to the community (Islamic Penal Code, 2012). The Code also contains special rules for cases of criminal insanity originating during or after the trial, which are divided based on the different groups of crimes in Sharia law (Islamic Penal Code, 2012). 
One thing that especially stands out as an example of Sharia's unreasonable severity is the fact that the government is allowed to forcibly hospitalize (which is actually a form of imprisonment, author's note) an insane perpetrator for an indefinite period of time (including, theoretically, for life, author's note), and all of that based exclusively on a discretionary decision of the public prosecutor - without the court's prior involvement - that is based on a single expert opinion. In addition to this, the fact that the prosecutor's decision can be appealed in court, but the court's judgement itself cannot be further appealed does not make it difficult for us to presume that the Iranian courts will have a close cooperation with the office of the public prosecutor, a phenomenon that has been observed in Iran's criminal justice system since the 1980s (Amnesty International, 2017). It is, therefore, clear that Iranian law is, despite having a civil-law-based definition of criminal insanity, not only disproportionally, but almost inhumanely rigorous and that, when the other elements of Sharia law are taken into consideration (the courts' discretionary powers, bias, interpretation in accordance with religious dogmas, decision-making freedom, etc.), Article 150 of the Islamic Penal Code opens up many possibilities for abuse of justice.

\section{Japan and the People's Republic of China}

The final comparative analysis is devoted to two Oriental legal systems - Japan and the People's Republic of China. Japan represents an ideal blend of common and civil law. Throughout the historical development of Japan's legal system, its jurists have drawn influences from both systems (they were initially European, and later, after World War II, mostly American) in order to form their own modern legal system following the Meiji Restoration. The People's Republic of China, on the other hand, presents a good example of an ideologically constructed (socialist) criminal law, similar to that of Iran, except for the fact that Chinese law is devoid of religious elements.

The Japanese Penal Code (Japanese: 刑法 Keihō) entered into force back in 1907 and remains in force to this day, with some changes and amendments. When analysing the legal content relating to criminal insanity (Japanese: 心神喪失 shinshinsōshitsu), it becomes obvious the Penal Code's regulation is very minimalistic, with Article 39, Paragraph 1 only briefly stating that "an act of insanity is not punishable" (Keihō, 1907). A brief analysis shows us that the Japanese lawmakers have neither defined criminal insanity nor have they listed any grounds for insanity within the Penal Code, prescribing only the legal consequences of established criminal insanity. Article 39 can be, thus, described as a blanket provision, a type of provision whose content must be complemented with other related provisions. The process of amending Japan's Penal Code was a complex, century-long process and it is difficult to briefly summarize how the current definition came to be, but it is important to state that a draft of a new Penal Code made in 1971 contained a different definition of criminal insanity. The draft's Article 39 defined criminal insanity as the perpetrator's inability to discern the meaning of their actions or to act in accordance with the law (Suzuki, 1973). Although the 1971 Draft never entered into force - meaning that Japan formally never adopted a new Penal Code, but rather just amended the existing one - the quoted definition of criminal insanity reflects the stance of Japanese legal theory and may be used as a reference point for the conclusion that Japan has a civil-law-based definition of criminal insanity. 
An important feature of modern Japanese law is the fact that the Penal Code's blanket provision is supplemented by a whole array of other laws dealing with public health, mental health and the treatment of mentally ill individuals, all of which supplement not just the definitions, but also the procedural elements of criminal insanity. While it is true that criminal insanity is rarely established before Japanese courts (Sakuta, 1991), the new Japanese Medical Treatment and Supervision Act (2005) provides a detailed set of procedures in the case that an insane person should commit a crime. In such cases, the public prosecutor will not initiate proceedings, but rather send the perpetrator to the District Court, where a panel consisting of a judge and a psychiatrist will perform a joint evaluation of the perpetrator, followed by a court decision regarding the patient's treatment (Nakatani, Kojimoto, Matsubara, \& Takayanagi, 2010). The court may issue one of the four orders - inpatient treatment, outpatient treatment and supervision, no decision, or a dismissal of the public prosecutor's request. These decisions do not represent a verdict in the classical sense, nor do they provide any decision on the offender's guilt (remember, there is no criminal procedure at all, author's note); they merely represent a court decision regarding the psychiatric treatment of a criminally insane offender (Nakatani et al., 2010), which is quite a revolutionary and progressive solution.

The People's Republic of China, in contrast, displays a series of almost fundamental differences in its approach to criminal insanity. The Criminal Law of the People's Republic of China was adopted in 1979, following a series of political upheavals in the country, and has been extensively modified throughout the years. It has been ideologically shaped in the spirit of Chinese socialism, being perceived as pronouncedly strict; in accordance with its ideological background, it provides the court bureaucrats and prosecutors with a large degree of authority, though it has been described as being much more fair and just than Mao's legislature (Fox, 1983). Criminal insanity (Chinese: 疯狂) is regulated in Article 18 of the Criminal Law; according to said article, a mentally ill offender will not be held criminally responsible. However, even the substantive provisions already contain several very strict regulations that put the mentally ill offender in a difficult position (PRC Criminal Law, 1979). On one hand, mental illness is the only basis for criminal insanity prescribed by the Law, which also states that the existence of a psychopathology must be established by the courts. This procedure is very rigorous, and there have been cases in Chinese history where an almost complete inability to function was required in order to establish criminal insanity, i.e., any sign of lucidity at all was taken as evidence of sanity. A good example is the case of the farmer Qui Xinghua, who was obviously insane, but because he was capable of filling out a psychiatric evaluation form, he was found to have been sane and was eventually executed (Freckelton, 2007). Furthermore, the mentally ill perpetrator's family or legal guardian have an obligation to keep the perpetrator under "strict surveillance" and provide treatment for them, but despite that, the government retains the right to enforce hospitalization for an indefinite period of time (PRC Criminal Law, 1979). Also, the Law explicitly states that a mentally ill offender whose mental disorder is not of a continuous nature and who commits the crime during a period of lucidity (so-called lucida intervalla), shall be held criminally responsible (PRC Criminal Law, 1979). This represents an additional restriction to an already very strict provision. In addition to all of this, the Law enables the punishment (albeit reduced) of even those individuals that 
have not fully succumbed to their mental disorder and retain a partial degree of control or consciousness (PRC Criminal Law, 1979). The following differences between the basic elements of criminal insanity in the respective legal systems are summarized in Table 1.

\section{Issue no. 2: Psychological profile}

In order to successfully determine whether the perpetrator of a crime was criminally insane, it is necessary to construct their psychological profile, which tells us what mental state the perpetrator was in, and which legal regime should be applied.

In criminal proceedings, a psychological or psychiatric profile is made as part of an extensive, all-encompassing expert evaluation procedure. During the expert evaluation, a court-approved expert (or experts) performs a complete diagnostic evaluation of the perpetrator, finally producing their conclusions (Kozarić-Kovačić, Grubišić-Ilić, \& Grozdanić 2005). In continental Europe, but also in a large share of other civil-law-based systems, evaluations are usually entrusted to psychiatrists, who produce the so-called expert psychiatric evaluations (Kozarić-Kovačić et al., 2005). In common law systems, however, it is common for the expert evaluation to also involve psychologists specialised in criminal psychology and criminal profiling. Despite criminal profiling being, primarily, an investigative technique aimed at producing the profile of an unknown perpetrator (unsub), psychological profiles of known offenders made using that method may prove themselves very useful in courts, which is still an unexplored field in continental Europe that holds enormous potential (Burazer, 2019).

An evaluation produced to determine whether the offender was criminally insane can have only two possible outcomes - the perpetrator is found to be either sane or insane. In the common law criminal procedure, the issue of criminal insanity is determined during hearings at the initiative of the parties themselves, meaning that the burden of proof usually lies with the defendant, who has to convince the court or the jury of their insanity; in the civil law criminal procedure, the court has to, ex officio, determine the (in)sanity of the offender. The court also plays a significant role in the evaluation process, as well as in determining its actual value as proof, all of this in relation with the offender's legally presumed sanity (Krapac, 2015). Namely, despite the evaluation being a professionally made document with a certain degree of authority per se, the courts are guided by the principle of free assessment of evidence, which provides the judges with absolutely no legal obligations in regards to the standard of proof required for any particular evidence, or its admission or disqualification. The opposite of free assessment is the formal evidence theory, which forces the court to use and respect certain quantities and qualities of evidence (e.g., at least two credible witnesses). According to the principle of free assessment of evidence, the court is, despite not possessing enough professional knowledge to evaluate the validity of some evidence, free to independently evaluate the importance and strength of every piece of evidence presented, even expert evaluations (which it can exclude if it intrinsically disagrees with them). The principle of free assessment of evidence is one of the fundamental aspects of modern criminal procedures and may be restricted only in cases explicitly prescribed by the law. 


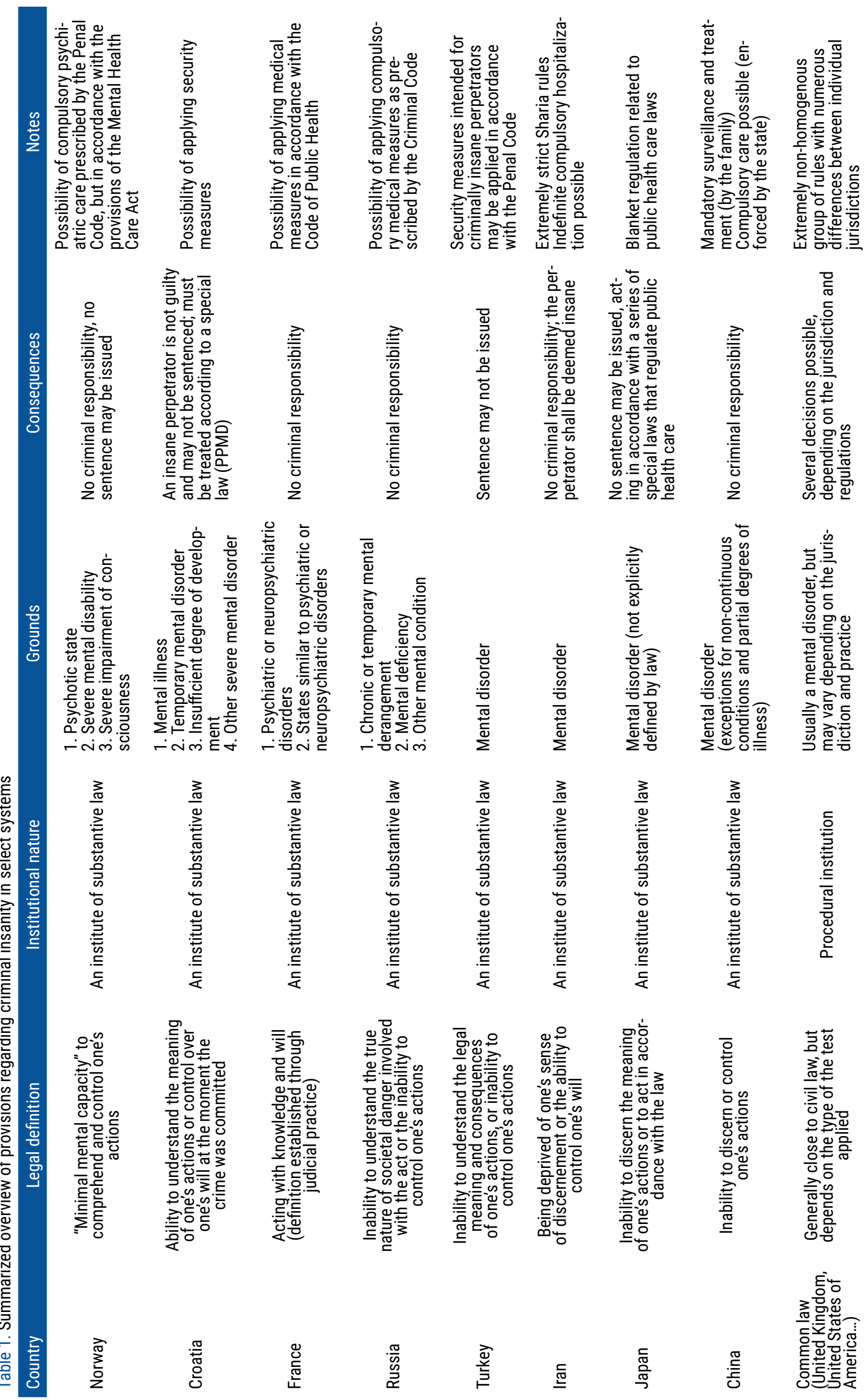


At the very beginning of the proceedings against Breivik, the question arose whether he was really in a psychotic state at the moment the crime was committed because that was one of the four grounds based on which Breivik could have been declared criminally insane. Namely, as previously stated, Norwegian law uses the medical method of establishing criminal insanity, which means that it is only necessary to determine that Breivik was in fact in psychotic state tempore criminis, without the need to establish a causal link between the potentially existing pathology and the crime itself. Breivik's extreme right-wing political views became the main focus of this issue since they were so radically opposed to the civilisational consciousness of the modern Norwegian society, that it was proposed that such radical attitudes could only be a sign of a severely disturbed, psychotic mind that has lost all touch with reality (Jacobsen \& Maier-Katkin, 2015).

Within seven days of his arrest, the Oslo District Court ordered an expert evaluation and named two experts who spent more than 36 hours interviewing Breivik and his mother, as well as analysing other available evidence such as the transcript of Breivik's interrogation and his medical files (Jacobsen \& Maier-Katkin, 2015). An important piece of evidence found by the experts, that also became a foundational basis for their opinion, was the fact that the National Centre for Child and Adolescent Psychiatry had described the four-year old Breivik as having a large potential for developing severe psychopathologies; however, the State took no further steps after that (Jacobsen \& Maier-Katkin, 2015). The experts concluded that Breivik began to mentally deteriorate and develop severe symptoms of schizophrenia sometime around 2006, when he quit his job, moved in with his mother and completely isolated himself from society. Using certain facts (social isolation, narcissism, unfounded delusions of grandeur), the experts concluded that Breivik is a paranoid schizophrenic who developed his radical right-wing attitudes as a consequence of his pathology (Jacobsen \& Maier-Katkin, 2015). Following the aforementioned diagnosis, Breivik was considered to have been in a psychotic state (i.e., criminally insane) tempore criminis.

Several comments are necessary before continuing with our analysis. From this perspective, the diagnosis of paranoid schizophrenia in Breivik's case appears just as bizarre as Breivik himself probably appeared to the experts during the interviews. Namely, there is no doubt that some of Breivik's symptoms may be ascribed to paranoid schizophrenia, but the two main attributes of this type of schizophrenia - auditory hallucinations and delusions - were not so pronounced (if present at all) in Breivik's case as to justify such a diagnosis. As far as it is known, Breivik had no auditory hallucinations (perceiving sounds without any stimulations, in this context usually consisting of non-existent voices, author's note) at all, and despite some of his ideas certainly being delusions of grandeur, they could hardly have been interpreted as chaotic (delusions, which are typical of psychosis and schizophrenia, are actually pathological delusions that reflect mental chaos, author's note), but rather as carefully constructed, organised ideas and plans that are more common for a personality disorder than for schizophrenia. Breivik had not manifested any explicit schizophrenic behavioural traits (his social isolation is easily explained by him writing the 1,500-page long racist pamphlet, as well as by him planning the upcoming attack), and while his ideas did sound bizarre, it is hard to imagine that his Islamophobic, xenophobic, misogynist and radical right-wing views (Breivik later identified as a Nazi, author's note) (Rognsvåg, 2015) are the result of paranoid schizophrenia, and not just sim- 
ply ideological stances. That line of thought opens up a perilous possibility of branding individuals as mentally ill based on their political views that might be in opposition to "civilisational standards" (whatever they may be) of a certain society; that is a method used by those exact ideologies that Breivik supported and advocated. The fact is, as further confirmed by recent events that there is a trend of right-wing radicalisation on European soil (Jacobsen \& Maier-Katkin, 2015), and there is practically no doubt that Breivik, who held such views even in his youth and had spent most of his time since 2006 online (with access to right-wing websites), is just an example of that radicalisation, rather than being a paranoid schizophrenic whose pathology caused him to become a fascist, Nazi and, according to his own words, Odinist. The first evaluation was met with widespread rejection in Norway and was deemed naïve, which prompted the Oslo court to order a new evaluation (Jacobsen \& Maier-Katkin, 2015).

A new team of two experts evaluated Breivik during the three weeks of his imprisonment, while also analysing other available materials (Jacobsen \& Maier-Katkin, 2015). Breivik turned out to be much calmer and more composed while talking to the new experts, admitting that some of his "delusions" were intentionally constructed narratives, or merely wishes that he himself recognized as unrealistic. The experts provided another perspective on Breivik's behaviour - his isolation and the return to his mother in 2006 were not symptoms of schizophrenia, but rather a pragmatic move that enabled him enough peace to plan, research, write and further develop his radical ideology. Anders Behring Breivik was, according to this expert opinion, nothing more than a radical right-wing extremist who, despite not being fully sane, was not psychotic either. The experts diagnosed him with a narcissistic personality disorder, which meant that Breivik had been sane because, even though he had a condition, narcissistic personality disorder was not known to lead to psychotic behaviour; therefore both the intellectual and the voluntary elements (i.e., "minimum mental capacity" required to adequately perceive the surrounding world) had been intact (Jacobsen \& Maier-Katkin, 2015).

Analysing his biography and publicly available data, it is clear that nothing in regards to Breivik indicates chaos or loss of control. He leaves the impression of quite a calm, cold and collected individual that plans his actions with great care, with particular attention given to detail and precision. Therefore, his isolation from society was the move of a pragmatical radical, and not a mentally ill individual whose pathology happened to manifest itself in that way. He used the time spent in isolation very carefully - writing xenophobic and racist blogs, actively playing video games, researching, writing, planning, etc. - i.e., he manifested all the mental characteristics that a paranoid schizophrenic individual never would. On top of that, it should not be forgotten that Breivik had been planning his terrorist attack in detail for years, displaying an admirable degree of organisation (sadly, the attack was carried out practically faultlessly, author's note), which is not characteristic of schizophrenia. His ideas of self-grandeur and his fictional plans - whose fictiveness he was well aware of - were not delusions, but merely a reflection of his narcissistic personality that perceived itself as something majestic. Breivik manifested practically all the traits of narcissistic personality disorder; just for reference, the American Diagnostic and Statistical Manual of Mental Disorders (DSM-5) (2013) lists the following diagnostic criteria for narcissistic personality disorder: (1) a grandiose sense of self-importance; (2) fantasies 
of unlimited success, power, etc.; (3) belief in being "special"; (4) demanding excessive admiration from others; (5) sense of entitlement to special treatment and privileges from others; (6) abusing and manipulating other individuals; (7) lack of empathy; (8) intense envy of others, and the belief he's the object of other people's envy; and (9) arrogant behaviour and superior attitude - so it remains quite unclear how the first group of experts managed to diagnose Breivik with paranoid schizophrenia.

No one doubted that Breivik suffered from some sort of mental disorder - both expert groups even agreed that he had narcissistic personality disorder - but the biggest dilemma was whether the nature of that disorder implied that Breivik should be declared criminally insane (Jacobsen \& Maier-Katkin, 2015). Faced with two contradicting expert opinions, the court concluded that the final decision on Breivik's sanity lies in their hands; so, after consulting other cases and provisions, the court concluded that, based on the characteristics of all his actions starting from 2006 until the attack itself, Anders Behring Breivik was sane.

\section{Issue no. 3: Procedural reflections}

Procedural reflections of the previous two chapters provide the juridical-pragmatic essence of this entire paper, but also of the entire issue, though they might appear to be the simplest part after going through the first two sections. Criminal proceedings are no "child's play", but the simplified and (occasionally) hypothetical "proceedings" for the selected systems found in this section will be much easier to understand now that the generalised background issues have already been addressed and analysed in detail in the previous sections.

\section{The procedure under Norwegian law}

The proceedings against Anders Behring Breivik were completed on August 24, 2012, when the Oslo District Court found him guilty on charges of terrorism, i.e., felonies against public security, prescribed in the old, now-deleted $\$ 147 \mathrm{a}$ - a severe disruption to the functions of vital importance to society and serious intimidation of the public (General Civil Penal Code, 1902). Since Breivik refused to recognise the legitimacy of the courts, he declined to appeal, and the proceedings were formally concluded when the initial verdict became final on September 8, 2012. The court acted following the conclusion that Breivik had been sane, and sentenced him to 21 years of preventive detention (Norwegian: forvaring), which was (and still is) the maximum penalty in Norway. Still, considering that Breivik was sentenced to preventive detention instead of imprisonment (Norwegian: fengselsstraff) - the difference between these two types of prison sentences lies with the fact that preventive detention represents a harsher sentence reserved for more heinous crimes, which carry with them a risk that regular imprisonment would not be enough to „protect the life, health or freedom of other persons”, and is carried out in special prison facilities with a stricter regime of control - there is also a possibility of his detention being prolonged indefinitely. The old Norwegian Penal Code, as well as the current Straffeloven, both prescribe the possibility of preventive detention being extended even past the gener- 
al 21-year maximum duration (Straffeloven, 2005). Each individual extension cannot last more than five years, but there is no limit to the number of possible extensions, which $d e$ facto means that Breivik could spend the rest of his life behind bars.

Our analysis of the hypothetical proceedings starts with Norway, but with the situation where the Oslo Court accepted the first expert evaluation, according to which Breivik had been criminally insane. Since the old and the new Penal Codes have the same regulations, with a few changes in style and numeration, we are going to use the current Code as a reference point (since it is one in force at the moment of writing). So, in the event of being declared criminally insane, Breivik would not have been liable for his crimes, in which case he would not have been tried in a regular criminal procedure. However, in the section concerning sentencing, the Penal Code prescribes a special type of sanction - committal to psychiatric care (Norwegian: overførung til tvungent psykisk helsevern) - which is, in fact, compulsory hospitalization. This type of sentence is regulated in Chapter 12 of the Penal Code and has two categories - one, when it is applied to psychotic or impaired offenders, and the other when it is applied to offenders with mental disabilities. Since Breivik's case falls into the first category, we will be focusing only on that one.

Norwegian law defines the conditions for compulsory committal very broadly, providing the court with great authority in determining all the relevant circumstances. The basic prerequisite is that the person has been declared criminally insane under $\$ 20$, which activates the relevant regulations of the Penal Code (Straffeloven, 2005), but also those prescribed in Chapter 5 of the Mental Health Care Act, which regulates court-mandated compulsory hospitalisation (Psykisk helsevernloven, 1999). The following paragraphs are an analysis of the relevant penal regulations only, and not the medical ones as they are prescribed in the Mental Health Care Act.

There is no doubt that the regulations above would have been applied to Breivik's case since he satisfied all the prerequisites required by the Code. Along with the previously mentioned basic prerequisite (the offender being declared criminally insane in accordance with \$20, author's note), in order to enforce hospitalisation, the court must believe that there is a need to protect the life, health or freedom of other persons, i.e., an obvious risk that the perpetrator might endanger those values (Norwegian: nærliggende fare). Furthermore, it is required that the perpetrator has either committed or attempted to commit a violent offence, sexual offence, unlawful imprisonment, arson or some other serious offence that represents a direct attack on the previously mentioned legal values (par. 1-2, art. 62 of the Penal Code). The law prescribes special conditions for less severe, but still dangerous crimes that represent attacks on the aforementioned rights (par. 3), as well as the possibility of applying these sentences to offenders who have repeatedly committed crimes that harm the society or are especially bothersome (par. 4).

Similar to the case of extending preventive detention past the prescribed duration, the committal to psychiatric care has no maximum duration and may last as long as the reasons that merited its imposition still exist, i.e., as long as there is an obvious risk of repetition (Straffeloven, 2005). Unlike preventive detention, this form of compulsory hospitalisation has to be reviewed regularly, while the authorised persons of interest can apply for 
its cessation after six or twelve months from the date the judgement ordering it became final (Straffeloven, 2005).

In the hypothetical case where Breivik had been declared criminally insane, he would still not have ended up as a free man, but would rather be subjected to compulsory psychiatric care, most likely until the end of his life, or at least for the duration of a regular prison sentence. In such a case, subsidiary medical provisions which supplement the penal regulations (compulsory surveillance and compulsory care) would have been activated (Psykisk helsevernloven, 1999). However, the fact is that such a decision would be far more beneficial for Breivik - he would never become a convicted murderer, he would not have a criminal record, nor would he be subjected to rehabilitation mechanisms necessary to strike his record from the criminal registry at one point. On top of that, he would probably be set free at one point, following his presumed "recovery", and there would be no further possibility to file criminal charges against him at any point after said "recovery".

\section{The procedure under Croatian law}

In Croatian law, the procedure against the criminally insane is not overly complicated. The system of sanctions in Croatian law is not as complex as the Norwegian one and knows only two types of punishment in the classical sense - imprisonment and a fine. So, if Breivik had been declared sane according to Croatian law, he would have been subjected to regular criminal proceedings and tried for either the crime of terrorism, as stipulated in Article 97 (Kazneni zakon, 2011), whose regulation is the same as in the old Norwegian \$147a, or, alternatively, for concurrent aggravated murders as stipulated in Article 111 in relation to Article 51 (Kazneni zakon, 2011), all depending on the legal qualification and interpretation of Breivik's act as either an act of terrorism or ideological vendetta (crusade). Croatia's legal practice has so far never encountered a case in which a single person murdered 77 people, so it would be interesting to see how the system would react in such a case, considering earlier decisions and available alternatives, but also the legislative limitations regarding sanctions and the concurrence of offences. In regards to sanctions, Breivik would have, if declared sane, no doubt been sentenced to long-term imprisonment, whose duration would probably be 50 years (in case of concurrent aggravated murders), since he would have satisfied the sentencing criteria that are applied in cases of where there is a concurrence of severe offences (Kazneni zakon, 2011).

If we are considering the situation where Breivik is declared criminally insane before a Croatian court, the procedural regime would simultaneously be both similar and different compared to the Norwegian one. Norwegian law treated Breivik as a potentially psychotic offender, which is equivalent to the Croatian criterium of mental illness. However, as it was explained in the previous chapter of this paper, this supposition is very difficult to maintain and a diagnosis of paranoid schizophrenia would by hardly sustainable even in the Croatian system. While Norwegian law doesn't have a modality wherein a personality disorder might serve as the basis for criminal insanity, the fourth criterium in the Croatian Criminal Code ("other severe mental disorder") opens up a possibility to deem Breivik's narcissistic personality disorder as basis for criminal insanity, since psychopathy is often listed as a typical example of “other severe mental disorders” (Novoselec \& Bojanić, 2013). 
The term here doesn't refer to the modern psychopathic personality disorder, but is rather an outdated term for all personality disorders that hasn't been used since the mid-20th century, despite still being preferred by Croatian legal theorists (Kozarić-Kovačić et al., 2005). Nevertheless, it seems very likely that Breivik would have ended up being declared sane even in Croatian law, meaning that a potential insanity defence would have been futile.

However, should it have happened that the courts did deem Breivik to have been criminally insane, they would have issued a verdict stating that the act had been committed while in a state of insanity, which would have eliminated Breivik's guilt, but at the same time activated the mechanism of compulsory admission to psychiatric care (Article 24, Paragraph 3 of the Criminal Code) in accordance with the Act on the Protection of Persons with Mental Disorders (Croatian: Zakon o zaštiti osoba s duševnim smetnjama). Compulsory admission to psychiatric care is one of the few types of admitting a person into a psychiatric facility and can be imposed on a severely mentally ill individual who presents a direct danger to himself or someone else's life, health or security, or rather, as prescribed in Chapter 7 of the PPMD (dealing specifically with the compulsory admission of the criminally insane), on a criminally insane individual who is at risk of repeating a severe crime and needs to be treated in a psychiatric institution (PPMD, 2014); compulsory outpatient treatment can also be imposed. It is interesting to note that Chapter 7 of the PPMD regulates the basic regime for the compulsory admission of the criminally insane, while the general regulations concerning the compulsory admission of the mentally ill, as stipulated in Chapter 6 of the same law, are applied only in those cases where the measure needs to be prolonged after the maximum duration prescribed by the law has passed (PPMD, 2014). The conditions for imposing compulsory care are practically the same in both Norwegian and Croatian law (severity of the disorder, risk of danger, danger to life, health or security, danger of recidivism), with the Croatian law demanding an explicitly determined causal link between the disorder and the endangerment (whereas Norwegian law does not even concern itself with the question of causality), and also permitting compulsory admission when the defendant is a threat to himself, and not just to others. The procedure for compulsory admission is non-contentious (PPMD, 2014), with the measure itself being issued by the court for an initial term of six months, with the possibility of extension up to the duration of the maximum sentence prescribed for the crime committed by the criminally insane offender (PPMD, 2014). Compulsory outpatient treatment can last no longer than five years (PPMD, 2014). However, if the conditions on which the measure was issued, as stipulated in Article 27, remain even after the maximum duration has passed, the measure can be prolonged, but only in accordance with the general regulations pertaining to the compulsory admission of the mentally ill (Chapter 6 of the PPMD) and not the criminally insane. In those cases, the procedure is initiated by the mental health facility itself, with the court deciding on it. In this case, each individual extension may last for no more than 6 months, but there is no limit to the number of potential extensions (PPMD, 2014). Croatia's system is, here, relatively similar to the Norwegian one - compulsory admission is possible, and its duration is related to the length of the sentence as prescribed by law. However, there is also the possibility of subsequent, indefinite prolongation in accordance with the general rules set out by the law, whereby the defendant is then no longer treated 
as a criminally insane offender, but rather as a person with a severe mental disorder. It is important to emphasize an essential difference between these two systems, and that is the very nature of this measure. Committal to psychiatric care in Norwegian law is a type of sanction and represents a punishment prescribed by penal regulations, while the medical measurers are of a subsidiary, supplemental nature. In Croatian law, compulsory admission is definitely not a form of punishment. It is even debatable whether it is a sanction at all as opposed to it being merely a compulsory medical measure since this measure in no way reprimands the offender, and it is rather a curative procedure that is in the perpetrator's interest. Similarly, other medical measures found in the PPMD, which are also not forms of punishment, are considered the primary norms for these situations, and not supplementary like in Norway.

\section{The procedure under French law}

The regular criminal procedure against a sane individual in France is not much different from those in Norway or Croatia, except for the legal classification of the criminal act and the sanctions themselves. As far as the legal classification is concerned, in French law, Breivik would have been charged with either the crime of terrorist acts (French: les actes de terrorisme), as stipulated in Article 421-1, which is practically identical to the Norwegian $\$ 147 \mathrm{a}$, or with numerous aggravated murders (referred to as assassinat in the French system) stipulated in Article 221-3. Despite there being several forms of aggravated murder in French law, only a murder committed with premeditation (French: préméditation) or in a specially heinous manner (French: gout-apens) represents the crime of assassinat (Code pénal, 1992). The exact qualification of the crime would here, just like elsewhere, depend on the interpretation of the perpetrator's motives, but also on past judicial practices, which would play a role in the public prosecutor's decision on how to qualify these acts. The sanctions, though, are somewhat different (Article 131-1 of the C.P.). On the one hand, French law has two types of prison sentences (détention being the milder, and réclusion the harsher type), while on the other hand, it also knows the sentence of life imprisonment (French: à perpétuité), which is not present in neither Norwegian nor Croatian law (Code pénal, 1992). However, regardless of whether Breivik would have been charged as a terrorist or mass murderer in France, he would have been sentenced to life imprisonment, given that it is a prescribed sentence in both cases.

The procedure against a criminally insane offender would be different. Contrary to Norwegian and Croatian law, the French Penal Code states only that a criminally insane offender is not criminally responsible (French: n'est pas pénalement responsable), i.e., states only the substantive elements of criminal insanity, without its procedural effects (Code pénal, 1992). The interpretation of this norm leads to the conclusion that a criminally insane perpetrator will not bear criminal responsibility for the crime they committed, but the Penal Code does not tell us the consequences of that fact, nor what happens to the said offender. The answer to that question lies within the French Code of Public Health (French: Code de la santé publique, C.S.P., 1953), which is a large and extremely complex code that regulates almost every aspect of public health care in France. So, in case the court decides that a criminally insane individual requires treatment and that they represent a danger to other individuals and the public order, they will initiate the procedure 
of compulsory committal to psychiatric care as stipulated in the Code. This procedure is described in the second book of the third part of the Code of Public Health (C.S.P., 1953). Compulsory committal in France is a purely administrative procedure performed by a prefect (French: préfet) at the behest and with the permission of the court. The procedure itself is too complicated and involves too many steps to be presented in detail in this paper, but it should be noted that the compulsory committal generally lasts as long as the grounds (danger) on which it was imposed are still present, i.e., there is no predetermined (fixed) limit.

The procedure of releasing a criminally insane perpetrator is likewise complex and differs from the general procedure for the release of the mentally disturbed as prescribed in the C.S.P. The general procedure for the release of the mentally disturbed is much simpler, as the decision can be based merely on the decision of either the psychiatrist in charge of the patient's care, the judge of liberty and detention (French: juge des libertés et de la détention) or a prefect (C.S.P., 1953). When the criminally insane are concerned, the procedure requires for an elaborated, consenting opinion of two psychiatrists that do not work in the same institution where the insane offender is being held. The release procedure is initiated only after acquiring said opinions, which tells us much about the strictness and the administrative complexity of the French treatment of criminally insane individuals, which is quite different from the Norwegian and Croatian procedures.

\section{The procedures under Russian and Turkish laws}

Considering the structural similarities between their penal regulations, Russia and Turkey may be grouped as countries whose, similarly to Norway, penal codes prescribe specific types of sanctions for the criminally insane, despite the nature of those specific sanctions being different than in Norway.

The Criminal Code of the Russian Federation differs from the three aforementioned civil law systems. It has a slightly different regulation of the crime of terrorism (Russian: террористический акт terroristicheskiy akt, Article 205) - "the perpetration of an explosion, arson or other action endangering the lives of people, causing sizable property damage, or entailing other socially dangerous consequences, if these actions have been committed for the purpose of violating public security, frightening the population, or exerting influence on decision making by governmental bodies, and also the threat of committing said actions for the same ends" - which means that in Russia, Breivik would have stood trial for the concurring crimes of terrorism and murder (Russian: убийство ubiystvo, Article 105), and not just for one or the other, as was the case in Norway according to §147a, or as it would have been the case in other civil law systems (Ugolovnyy kodeks Rossiyskoy Federatsii, 1996). Though Russian law does not formally use the term "aggravated murder", the Criminal Code actually lists more than ten aggravating circumstances of murder (meaning that aggravated murder does exist in Russian penal law, author's note), out of which the following are applicable in this case: the murder of two or more persons (a), exceptional cruelty (d), murder committed by a generally dangerous method (e), reasons of political, ideological, racial, national or religious hatred (l). Cases of concurrence generally require that one consults the regulations regarding unified sentencing, but since the 
Russian Criminal Code prescribes life imprisonment - even the death penalty - for both of these crimes, there is no need for that in this case. Because there is a moratorium on the death penalty in Russia since 1996, it is safe to conclude that Breivik would have been sentenced to life imprisonment had he been tried as a sane offender in Russia (Ugolovnyy kodeks Rossiyskoy Federatsii, 1996).

The Turkish situation is even more peculiar because the Turkish Penal Code (Turkish: Türk Ceza Kanunu, 2004) does not even list the crime of terrorism, but instead regulates it in Article 1 of the special Law on Fight Against Terrorism ("criminal action conducted by one or more persons belonging to an organisation with the aim of changing the attributes of the Republic as specified in the Constitution, the political, legal, social, secular or economic system, damaging the indivisible unity of the State with its territory and nation, jeopardizing the existence of the Turkish State and the Republic, enfeebling, destroying or seizing the State authority, eliminating basic rights and freedoms, damaging the internal and external security of the State, the public order or general health”), which thus functions as a subsidiary penal regulation (Terörle Mücadele Kanunu, 1991). Although the Law on Fight Against Terrorism (Terörle Mücadele Kanunu, 1991) states that aggravated murder from Article 82 of the Penal Code could be a terrorist act, it counts as such only if it is performed as part of the activity of a terrorist organization (Terörle Mücadele Kanunu, 1991). Other criminal acts that are defined as terrorism in Turkey are not comparable to Breivik's actions, which in turn means that Breivik would have been charged with 77 aggravated murders (Turkish: nitelikli kasten öldürme) in concurrence (Article 82 of the Penal Code), most likely based on premeditation (Turkish: tasarlayarak) as the aggravating criterium (Türk Ceza Kanunu, 2004). The problem with Turkey’s counter-terrorist laws lies in the fact that they are interpreted within the context of the governing political structure, which resulted in them not actually being used to deal with real terrorists, but rather as a tool for the government to deal with political and ideological opponents, as well as the media, who are often targets of government repression and are branded as terrorists and those who undermine the State, which automatically puts them within the jurisdiction of the controversial Law on Fight Against Terrorism (Amnesty International, 2018). Ironically, Breivik would probably not fit the criteria for a terrorist according to the same Law. After a quick grammatical interpretation, we can conclude these regulations are not shaped so that they encompass the specific, individual and highly personal acts of the terrorist Breivik, given that his goal was not to undermine the State and public order. As far as sanctions go, Turkey has a dualistic system consisting of imprisonment and judicial fines (Article 45 of the Penal Code), the former of which has three types (Article 46 of the Penal Code) - aggravated life imprisonment, life imprisonment and imprisonment for a specific term (Türk Ceza Kanunu, 2004). Since the punishment for aggravated murder is aggravated life imprisonment, that means that, in this case, Breivik would have been sentenced to life imprisonment in a heavily guarded, high-security prison facility (Türk Ceza Kanunu, 2004).

When discussing criminal insanity in Russian law, we can, like in Croatian law, refer to criminal insanity based on the third, general clause - "other mental condition" - in which case it would have to have been proven that Breivik's personality disorder had influenced his intellectual or voluntary elements tempore criminis. In the aforementioned 
case, Article 21, Paragraph 2 of the Criminal Code points to the possibility of imposing compulsory medical measures (Russian: принудительные меры медицинского характера prinuditel'nyye mery meditsinskogo kharaktera) from Chapter 15 (Article 97 - 104), which is the first chapter in the section of the law that discusses other penal measures. These are not punishments in the classical sense, but rather specific penal measures with certain specialised elements that have to be supplemented by the use of other, specialised laws, which is very similar to the regulation in Norwegian law. There is a total of four compulsory measures, one involving compulsory outpatient treatment and observation, and three types of compulsory committal - compulsory treatment in a specialised mental hospital, compulsory treatment in a specialised mental hospital with intensive observation, and compulsory treatment in a psychiatric hospital of specialised type with intensive observation. They can be imposed on a total of four groups of offenders, only one of which - the criminally insane offenders - is of interest to this paper (Ugolovnyy kodeks Rossiyskoy Federatsii, 1996). The type of compulsory medical measure that is to be imposed is determined individually based on the perpetrator's traits and the severity of his condition, with the entire procedure being strictly controlled by the courts, acting on the advice of psychiatrists and forensic psychiatrists. There is an obligation to review the patient's condition at least once every six months, and if the experts conclude that there has been no improvement, the measure can be extended, initially for six months, then for a year. There are no limits regarding the total number of possible extensions, which means that there is a possibility that the criminally insane offender could remain in a psychiatric institution for the rest of his life (Ugolovnyy kodeks Rossiyskoy Federatsii, 1996).

The Turkish law, however, uses the general term "mental disorder" as the only possible basis for criminal insanity, which means that proving the causal link between the disorder and crime would have been the key to determining whether Breivik had been sane or not (Türk Ceza Kanunu, 2004). Like elsewhere, criminally insane perpetrators in Turkey cannot be punished but security measures can be imposed on them. The most significant ones in these cases are the specialised security measures for the mentally disordered, as stipulated in Article 57 of the Penal Code (Türk Ceza Kanunu, 2004). The courts are the only institutions that can impose these measures, and the necessary condition for their application is the existence of a risk for society (Türk Ceza Kanunu, 2004). The Penal Code also stipulates obligatory control of the criminally insane perpetrator, but at the same time does not specify either the duration of these measures or their limitations, which suggests that in Turkey too, they could be extended for life.

\section{The procedure under common law}

Common law has briefly been discussed in the first part of this paper, and because of the large differences that exist between the individual common law systems, we are not going to provide a detailed analysis of each of them, but rather present the common procedural traits and some interesting differences, primarily focusing on the legal systems of the United Kingdom and the United States of America.

As far as regular common law criminal proceedings are concerned, it may be stated that Breivik, if he had been declared sane, would have been charged with either multiple mur- 
ders or for a terrorism-related crime, but the exact qualification would depend on the jurisdiction and the individual penal statutes (Burazer, 2016). A good comparative example in common law are mass school shootings, but also the 1995 Oklahoma City bombing. Mass shootings are specific because they usually end with the shooter committing suicide, which is why there are usually no criminal proceedings. However, the 2012 Oikos University shooting in California left behind a surviving perpetrator, One L. Goh, who was ultimately charged with seven aggravated murders, which coincided with the total number of victims of that shooting (Goh ended up being declared insane, but that is not relevant for this digression, since we're discussing the similarities between the incriminations themselves, and not the mental state of the offender, author's note). Further, the infamous terrorist Timothy McVeigh, who perpetrated the 1995 Oklahoma City bombing, was charged, among other things, with eight aggravated murders, but his full indictment was much larger. Although these examples are not completely identical, there are enough parallels between them to conclude that Breivik would have been, at least under U.S. laws, prosecuted for the aggravated murders he had committed, with the possibility of adding other charges to the list, most likely connected to the terrorist character of his attacks. As far as punishment is concerned, since all of the aforementioned common law systems have life imprisonment (except for the state of Alaska), there is no doubt that Breivik would have been imprisoned for life, while in some parts of the United States, he would also have been a very likely candidate for the death penalty.

As far as criminal insanity is concerned, we can state that the three systems under British law have very similar procedural regulations. The Crown will initiate criminal proceedings against a criminally insane offender, and if he is successful in using the insanity defence in court, he will be declared either "not guilty by reason of insanity" or "guilty, but insane". Scots law has an additional institute related to criminal insanity - insanity in bar of trial - which allows for the temporary suspension of proceedings against a criminally insane offender, with the possibility of them being continued and concluded at a later date, in case the offender recovers from his illness (Burazer, 2016). U.S. courts usually allow a defendant to use the insanity defence, and though every state has its peculiarities, it can be, generally, said that such cases have only two possible outcomes - "not guilty by reason of insanity" or "guilty, but insane"; other possible outcomes do not appear in U.S. practice (Burazer, 2016). The procedural consequences may also vary, and it is important to note that the issue of the insanity defence in common law is closely related to the issue of competence (in this case, competence to stand trial), or fitness (in British law), which is not the case in civil law systems.

So, if Breivik had been declared criminally insane in British law, regardless even of his fitness to stand trial, he would have very likely been committed to compulsory psychiatric care until his recovery, i.e., without a fixed term. The same would have happened in the United States, where an insane defendant can either be released in case of a "not guilty by reason of insanity" verdict, though that rarely happens in practice; found guilty, but not sentenced in case of a "guilty but insane" verdict; or committed to compulsory care in a psychiatric facility, where he could, de facto, spend the rest of his life. The latter, nominally a medical measure, thus becomes a form of imprisonment (or its informal surrogate), a 
sentence that is generally not imposed on the criminally insane under U.S. law (Burazer, 2016).

Although also based on precedents, the British system is much more firmly based on written statutes and acts, which means that the compulsory committal to psychiatric care cannot become a surrogate for imprisonment in Britain. The American system, on the other hand, is much more dominated by the pragmatism of its precedents and case law. That amounts to a nominally medical measure being transformed into a form of punishment, which is generally prohibited, just for the sake of ensuring public safety, something which is additionally emphasized by an overly complicated procedure for the release of the criminally insane, which in turn opens many possibilities for manipulation.

\section{The procedure under Sharia law (Iran)}

We have already discussed the fundamental aspects of Sharia law in the Islamic Penal Code of Iran, which is why, in this part, we only need to refer to those aspects that are essential for the understanding of this complex system. Unlike the systems previously described, Iranian law's regulation of criminal insanity is much easier to analyse than its regulation of sanity, considering that all of the relevant substantive and procedural norms are prescribed in the previously analysed Articles 149 and 150 of the Islamic Penal Code. The only questionable aspect of this issue is how the Iranian courts would have treated Breivik's personality disorder, considering the fact that the Penal Code's only basis for criminal insanity is a mental disorder, without any further specifications. However, the author believes that the strict Iranian courts would have been more prone to deem Breivik sane, rather than insane.

In order to fully clarify how Iranian law would treat a sane offender, it is necessary to observe the basic structure of the Islamic Penal Code. The new Islamic Penal Code made very little changes to the old one - out of five books, only three (I-III) of them have had any changes whatsoever, which means that Iran never made a complete reform of its criminal justice system, as affirmed by the All Human Rights for All in Iran (AHRAI) organisation in its report (AHRAI, 2014). The Islamic Penal Code is divided into five books - Preliminary Regulations (Book I), Hudūd (Book II), Qișāṣ (Book III), Diya (Book IV), and Ta'zir (Book V). The first book contains and mostly presents the general part of criminal law, while the other four books roughly represent what Western countries would refer to as the special part of criminal law. All four of those books are, naturally, based on Sharia law, i.e., on the punishments prescribed by Sharia law. To sum it up, it could be stated that Sharia law recognizes three basic groups of punishments (Hallaq, 2009). The first group, hudūd, deals with punishments set and fixed by Allah. These punishments are actually immutable "divine punishments" and stem from the dogmatic foundations of Sharia law. Hudūd punishments are the most severe punishments in Islamic law. Qiṣāṣ (Arabic: صاصق) is a doctrine of revenge or retribution, i.e., the Islamic version of the lex talionis ("an eye for an eye, a tooth for a tooth"), a principle stemming from the Code of Hammurabi. Crimes that belong to this group are punished in the same way that they have been committed. Instead of retribution, the victim or the injured party may receive (or do receive) monetary compensation for the damages caused (so-called bloodwit or blood money); that compensation is 
called diya (Arabic: ثيد). Diya represents the main content of the fourth book, and it may be paid to the victim or the injured party's kin as well. The last group consists of the sanctions based on the ta'zir dogma (Arabic: ريزعت); these are the sanctions that are not predetermined in Sharia or some other dogma, but rather set by a judge or the head of state. This judicial authority is, of course, derived from Sharia rules, but the rules themselves do not determine the sanctions, which are determined and imposed upon by the judges.

The four books of the "special part" are grouped by punishments prescribed for certain offences, which means that the offences themselves are not grouped based on their general typology (as is usual), but rather on the punishments prescribed for them. So, because the offences are grouped by types of punishments, some of the groups are typologically quite heterogenous and do not necessarily contain similar offences, nor offences that protect the same social and legal values, as it is the case in civil-law-based penal codes.

As far as Breivik's case is concerned, the biggest dilemma is how the courts would have classified his offence - as terrorism or as mass murder. The importance of this qualification is vital since it determines the group of punishments that can be applied in a specific case. So, in the first case, if the courts were to classify his actions as terrorism, Breivik would fall under the jurisdiction of the first book, containing the hudūd punishments. The offence in question is called muhāaribah or moharebeh (Persian: هبراحم) - a Persian term derived from the synonymous Arabic term hirābah (Arabic: "piracy" or "illegal war", but in the legal context usually covers crimes like armed robbery, rape and terrorism - and is regulated in Articles 279 - 285 of the new Islamic Penal Code (Islamic Penal Code, 2012). According to the fixed hudūd rules, the perpetrator could be subjected to capital punishment by hanging, or other punishments like crucifixion, amputation of the right arm and the left leg, or banishment (Islamic Penal Code, 2012); these punishments are a good illustration of not only the strictness but also the extreme disproportionality and brutality of ḥudūd punishments.

If, on the other hand, the courts were to interpret these actions as serial or mass murders, Breivik would no longer fall under the ḥudūd doctrine, but rather under the qiṣass rules, considering that murder is an earthly crime most suited for retributive punishment. In this case, the victims' kin would have the right to demand an equal punishment, but also to exchange the retribution for monetary compensation (diya). Book III of the Islamic Penal Code still has not been translated into a major language, so access to detailed regulations was limited; however, fragmented reports are available for use as reference points (AHRAI, 2014). In any case, this qualification would, at least in principle, present a much better solution for Breivik, since it allows for less strict alternatives, while under hudūd, the punishment would be extremely severe. Considering that fact alone - the possibility of total retribution - it is almost certain that Breivik would have been prosecuted as a terrorist according to the hudūd rules.

\section{The procedure in Japanese law}

The Japanese procedure for the compulsory committal of the criminally insane has been described as part of the analysis of substantive norms. In this section, we are going to focus solely on the procedural treatment of sane offenders. 
The Japanese Penal Code knows five main types of punishments (death penalty, imprisonment with or without work, fine, misdemeanour imprisonment without work and a petty fine), along with a single type of supplementary punishment (confiscation), and with no security measures or other types of sanctions (Keihō, 1907). The death penalty is executed by hanging, while imprisonment with or without work may be for life or a set duration (minimum 1 month, maximum 20 years). As for the special part of the Penal Code, it is interesting to note that Japan knows only the basic form of murder (Japanese: 殺人 sastujin), as stipulated in Article 199, and the punishments prescribed for it are the death penalty, life imprisonment with or without work, or imprisonment for at least 5 years (Keihō, 1907). Japan does not have any aggravated forms of murder in its Penal Code (aggravated murder included), which is quite a rare occurrence (a similar practice exists in Iceland, for example, whose General Penal Code only regulates "regular" murder in its Article 211, author's note); the case becomes even more interesting once we consider the fact that Japan's Penal Code doesn't list the crime of terrorism, either. It does, however, list the crime of insurrection (Japanese: 内乱 nairan, Article 77), which does not encompass elements of terrorist actions, but does include actions aimed at subverting the state order, i.e., an attack upon the State and its authority, which may be interpreted as an act of terrorism (Keihō, 1907). This example is particularly relevant because Aum Shinrikyo, the terrorist cult responsible for the infamous 1995 Tokyo subway sarin attack, was charged with, among other things, attempting to overthrow the State order, i.e., insurrection. This was also one of the charges the prosecution brought up against Shōkō Asahara, the cult leader who was found guilty and eventually executed in 2018. This terrorist group was primarily charged with multiple murders (the Japanese rules on concurrence, Articles 45 -55 , allow for prosecution of each murder as part of the same criminal procedure, which means that there can be no continuous offence). However, a part of the charges that was related to their terrorist activities was connected to the crime of insurrection from Article 77. (Ronczkowski, 2017).

To conclude - if Breivik had been deemed sane under Japanese law, he would have been charged with 77 individual murders, with a possible concurrence with the crime of insurrection, and considering the number of victims and the severity of the crime, would have almost certainly been sentenced to death.

\section{The procedure in the law of the People's Republic of China}

The situation in the People's Republic of China is somewhat different. Just like in the Japanese example, the issue of the Chinese legal treatment of the criminally insane has already been touched upon in the analysis of the substantive norms. This section will focus on the analysis of the relevant norms stipulated in the Criminal Procedure Law (CPL) and the Mental Health Law, after which it will move on to the specific regulations of the general and special parts of criminal law that apply to this case.

The People's Republic of China adopted its first Mental Health Law in 2012; it entered into force in 2013, which was considered a revolutionary step in the country, despite the law's shortcomings. Care for the mentally ill in China has traditionally been entrusted to the patient's family (who also made decisions regarding hospitalisation), so the new Mental 
Health Law created a Copernican turn of sorts in that field, because, for the first time in Chinese history, it prescribed, at least in principle, voluntary hospitalisation as a rule, which was a very progressive decision (Phillips et al., 2013). Proclaimed in Article 30 of the Mental Health Law, this voluntary element has two exceptions - the risk of self-harm and the risk that his behaviour might endanger and harm others - when the administrative procedure of compulsory committal is initiated (PRC Mental Health Law, 2012). However, this pertains primarily to civil committal, where there is no judicial input, while the penal committal, where there is significant involvement of the courts, is regulated in the special part of the amended Criminal Procedure Law (amended in 2012), which regulates the procedure of compulsory committal to psychiatric care. It can be observed that China's regulation is different due to the fact that the compulsory committal is not regulated in a special act (that act deals only with the fundamentals of mental health care), but rather in the special part of the main procedural act.

According to the regulations set in the CPL, a criminally insane individual who poses a risk of endangering public security or the personal security of other citizens may be put under compulsory psychiatric treatment based on a court order (PRC Criminal Procedure Law, 1979). The procedure involves the participation of government institutions and the People's Procurator (public prosecutor), while the final decision is made by a People's Court following a hearing (PRC Criminal Procedure Law, 1979). The duration of the compulsory treatment is not limited, and may generally last until the psychiatrists in charge of providing care conclude that the risk of endangerment no longer exists; in such cases, patient assessment is mandatory and must be performed regularly (PRC Criminal Procedure Law, 1979). The family of the committed individual can appeal for a revision of the initial decision, i.e., demand for the committed individual to be released. As it can be seen, China has a significantly different normative structure regarding the issue of compulsory committal. While the procedure is somewhat stricter compared to Western countries, it is not as strict as the earlier analysed Iranian law.

Sane perpetrators are dealt with according to the regulations set in the Criminal Law, meaning they are subjects to regular criminal proceedings as stipulated by the Criminal Procedure Law. Just like the Japanese Penal Code, China's Criminal Law differentiates between the principal (control, criminal detention, fixed-term imprisonment, life imprisonment and the death penalty) and supplementary punishments (fines, deprivation of political rights and confiscation of property), which differ in number and structure (PRC Criminal Law, 1979). These punishments are imposed on sane perpetrators. As far as the qualification of the criminal act is concerned, Breivik's case could have been categorized either as a crime that endangers public security, or as a crime infringing upon the rights of the person and the democratic rights of citizens. In the first case, it is a terrorist crime as stipulated in Article 114, i.e., its qualified form that involves death, as stipulated in Article 115 (PRC Criminal Law, 1979). However, since these crimes do not encompass mass murder by firearms, the Utøya incident needs to be evaluated within the scope of Article 232, which regulates the intentional murder of another person (PRC Criminal Law, 1979). Breivik would have most likely been charged with the concurrence of these two crimes, but since both of them have the same prescribed sentences - a minimum of 10 years of 
imprisonment, life imprisonment, or the death penalty - it is highly probable that Breivik would have been executed in this case.

As we have presented, Breivik's case looks quite different in different jurisdictions, which shows us all the diversity, but also the beauty of comparative law. The same set of facts in another environment appears different and produces quite different outcomes, reflecting the mosaic of various legal norms around the globe. While the regulation related to sane offenders varies significantly between different systems, mostly because of the significantly different structure of incriminations in the special parts of the penal codes, the procedural effects are fundamentally the same - in both cases (had he been declared sane or criminally insane), Anders Behring Breivik would have been removed from society, whether by means of imprisonment or compulsory committal to a psychiatric institution.

However, though the procedural outcomes may be the same, the procedural mechanisms leading to them are quite different and display all the specific attributes of various national legal systems even more than the differences in substantive law. The procedural mechanisms are a reflection of the system's perception of the role of criminal law in society and of the functions of its norms, and thus may vary from quite liberal systems such as the Norwegian one, via progressive solutions like the Japanese one, to very strict and conservative systems such as the Iranian or Chinese ones. All the similarities and differences between the systems are summarized in Table 2.

\section{Raison d'être?}

Keeping in mind the fact that pure comparison is not a reason in itself and that papers should not be written just for the sake of comparison, the author deems it necessary to elaborate on two significant - yet underlying - reasons behind this paper. Namely, the more obvious reason of this article was to present and analyse the case of Anders Behring Breivik from a new (or different) perspective, which we have done in the preceding paragraphs. Now we should have to explain why the comparative aspect was so emphasized in this paper and what questions arise from it.

Before we continue, it is important to note that the issues in question are related to all three aspects of the paper - the substantive, the procedural and the psychological. Sadly, these issues are individually too extensive for us to analyse each of them here thoroughly, but they still merit a brief commentary, at least as the ostensible raison d'être of the comparative analysis presented in this paper.

We are going to start with the psychological aspect since it is the simplest one. Namely, a comparison of the possibilities arising from profiling an offender usually raises the question of the effectiveness of profiling individuals who have committed severe crimes such as this one (namely, it seems that being declared criminally insane, despite all the possible 
Table 2. Summarized overview of the procedural regulations in the selected systems

Country Sanity

- prosecution under \$147a (terrorism) of the General Civil Penal Code

Norway - sentencing to preventive detention for a maximum of 21 years

- probable extension of the preventive detention over the prescribed limit (for life)

Croatia (aggravated murder), in connection with the norms on concurrence (Article 51)

- sentencing to long-term imprisonment of 40 years (or 50 years if the rules of concurrence are applied)

France

- prosecution under Article 421-1 (terrorism) or Article 221-3 (assassinat)

- highly probable sentencing to life imprisonment (French: réclusion à perpétuité)

- concurrence of offences set in Article 205 (terrorist act) and Article 105 (aggravated murder)

Russia - probable sentencing to life imprisonment - the offences are punishable by the death penalty, but there is a moratorium on its execution with a small chance of applying anti-terrorism laws - probable sentencing to life imprisonment

- variant no. 1 (hudūd): prosecution for moharebeh

(Articles $279-285$ ) ---> probable death penalty

Iran - variant no. 2 (qișasss): prosecution for classic, secular murder ---> lex talionis (death for death), with a possibility of replacing it with bloodwit (diya)

- prosecution under Article 199 (murder), possible concurrence with Article 77 (insurrection)

Japan - probable death penalty by hanging (alternatively life imprisonment)

- concurrence of crimes from Article 115 (an aggravated form of terrorism) for the bombing, and Article 232

China - probable death penalty (alternatively life imprisonment)

- the complexity of individual systems dictates the probable prosecution for some form of terrorist of-

$\begin{array}{ll}\text { Common } & \text { fence or for individual aggravated murders } \\ \text { law } & \text { - probable sentencing to life imprisonment (present in }\end{array}$ all jurisdictions), with the death penalty being a possibility in some jurisdictions
Criminal Insanity

- no criminal liability, a probable affirmation of the offender being a danger to society

- imposing compulsory committal to psychiatric care

until the danger has passed (most likely for life)

- subsidiary application of the Mental Health Care Act

- the verdict that determines the crime was commit-

ted while in a state of criminal insanity (no criminal liability)

- probable application of the regulations set in the

PPMD and related to the compulsory admission of criminally insane individuals (up to the duration of the sentence it replaces)

- possible application of regulations related to the compulsory admission of the mentally ill (which can be extended indefinitely)

- no criminal liability

-subsidiary application the regulations defined in the Code of Public Health

- administrative procedure of compulsory committal (generally without a fixed term of duration)

- complicated administrative procedure for release

- no criminal liability and punishment

- compulsory medical measures ---> imposing compulsory committal (3 variants, depending on the complexity of the case)

- unlimited number of possible extensions in accordance with the conditions prescribed by the law

- no criminal liability, punishment may not be imposed

- possibility of imposing specialised security measures against the criminally insane

- compulsory committal for an indefinite period

- no criminal responsibility

- possibility of compulsory committal for an indefi-

nite period of time based on the public prosecutor's request, approved by the courts - limited possibilities of appeal

- no criminal liability, no criminal proceedings - application of the procedures and measures set in the Medical Treatment and Supervision Act - possibility of imposing compulsory committal or outpatient treatment (no pre-defined duration)

- no criminal liability

- care and oversight usually entrusted to the family, but the government retains the right to impose compulsory inpatient treatment

- application of the regulations set in the Criminal

Procedure Law (administrative procedure for imposing compulsory committal with indefinite duration)

- subsidiary application of the Mental Health Law

- regular criminal proceedings, whose outcome depends on the (un)successful usage of the insanity defence

- generally, two possible verdicts - "not guilty by reason of insanity" or "guilty but insane"; Scots law model - possibility of being released or not punished (rarely). or compulsory committal (indefinite duration)

modalities, is more beneficial for the offender than the stigma of being a convicted offender, author's note). At least nominally and at least in Western countries, there is a growing movement to rehabilitate criminally insane individuals and reintegrate them into society, while sane serial killers spend the rest of their life behind bars, assuming they are "lucky enough" to live in a jurisdiction that does not have the death penalty. However, that is not the issue in focus here. The issue in focus is the fact that, if a mass murderer and terrorist 
such as Breivik would be acquitted of criminal responsibility and institutionalized in a psychiatric facility, there would be probably such a severe public outcry that the system might possibly collapse. Cases from around the world (especially from the United States) show us that serial and mass murderers are almost always declared sane in order to remain within the scope of regular criminal proceedings (the cases of Ted Bundy, Andrei Chikatilo, Alexander Pichushkin, David Berkowitz, John Wayne Gacy, etc., can be mentioned as confirmation, author's note). Because these are usually individuals with severe mental disorders (usually severe personality disorders, author's note), the question arises as to the reason for such procedures: the author believes that such practices are due to the public and societal interests - the interest of protecting the society from such dangerous individuals exceeds their individual rights and the issues of their psychological states. Despite such practices, there are a lot of examples where an offender being declared sane is not only doubtful but also most likely wrong (one of those being the serial killer Jeffrey Dahmer, who suffered from a severe borderline personality disorder, author's note). The issue of profiling such cases thus becomes extremely relevant in this context, where we have a direct collision between the law as an abstract, unbiased and non-personalized system, and society, whose interests are undoubtedly subjective.

The second issue concerns the nature of criminal insanity and is related to both its substantive and procedural interpretations. Namely, the issue of criminal insanity is not only one of the oldest, but also one of the most important questions in criminal law, and represents an essential cog in the machinery of criminal justice systems. However, the theoretical foundations of this institute have been formed during a period of history when our insight into the human psyche was quite poor compared to today's; it is a fact that the legal definition of insanity has not changed drastically for more than 1,500 years (Walker, 1985), probably even several millennia. That means that we are still dealing with a definition that was created in a period when our knowledge of the human psyche was of an anecdotal nature, based more on mere observation and deduction (sometimes even induction) rather than precise scientific evidence. It is, thus, reasonable to conclude that the definition is old and outdated since many of the Ancient and even pre-modern interpretations of the human psyche (e.g. phrenology, physiognomy, etc.) have been proven wrong. There has certainly been a strong paradigm shift in understanding the mechanisms of the human mind. Modern psychology started in 1895, and the definition of criminal insanity is at least 1,400 years older than that, and it has not changed despite the breakthroughs (criminal) psychology had during the 20th and 21st centuries.

So, even though our understanding of the human psyche kept improving, insanity remained fixed in its historical definition, which is unable to completely face the challenges that the human psyche can sometimes put in front of the criminal justice system. The implications of this fact are enormous. The definition of criminal insanity in substantive law is the basis for all further legal proceedings, and since we are dealing with an outdated definition that does not recognise the distinction between "classical disorders" (such as schizophrenia or bipolar disorder, i.e., those disorders that have a clear influence on a person's perception of reality and thus inhibit his reason) and "modern" systematisations that include personality disorders, dissociative disorders and similar complex disorders, we are clearly in a situation where the criminal justice system cannot fully and completely 
justly apply itself in some specific cases, the results of which could be very inadequate. This, of course, has its procedural implications. People who are undoubtedly ill (persons with personality and/or dissociative disorders, author's note) are being treated as sane because of the danger they posses and a certain level of reason (the law does not quantify insanity in such a way, nor should it, author's note) they still have.

In Breivik's case, it is fortunate that a more detailed analysis of his psyche reveals that there is no basis for criminal insanity, even if criminal insanity were to be redefined in order to adequately face the issues of personality disorders and similar complex disorders (such as impulse control disorders or the dissociative identity disorder, author's note). However, just like with the previous issue, there are numerous examples (Ted Bundy, Albert Fish, Billy Milligan, author's note) where the current definition of criminal insanity is unable to provide an adequate answer.

What does that mean in the sense of potential reformation? The history of crime is rich with examples - and we are only talking about the notoriously famous ones, not the ones that never reach historical books and encyclopaedias - where evidently ill people have been tried and sentenced as sane individuals. Such situations are, we think, without a shred of doubt grave miscarriages of justice and the comparative analysis we made has shown that these miscarriages are not just a local issue, but a globally present problem as even those system who have very different perceptions of criminal law and different foundations still present the same symptoms of such miscarriages. It was - because of that - important to provide a broader look at the issue of criminal insanity to emphasize how the systems do not function properly when this psychological issue is in question.

The outdated definition needs to be changed and expanded to adequately react to the issues that arise from improperly treating certain specific cases and disorders. This will have consequences on the procedural treatment of such cases - the procedure would have to be changed, and the rules of proving insanity in court would also have to be redefined but also the sanctions concerning such offenders, as they are fit for classical punishments, but rather for specific medical measures, some of which have also been presented in this paper.

\section{Discussion and conclusion}

In the first part of this paper, we analysed the issue of insanity in substantive criminal law; this issue is not so problematic per se, but it is interesting when approached from multiple different perspectives. Although there are more systems around the world than we have analysed in this paper, the intention was to present some examples that stand out by virtue of their specific regulations and by being a part of a certain legal system. In light of that goal, Norway, Croatia, France and Russia were selected as examples of a pure civil law model, while Turkey could be included only tentatively because it displays significant differences from traditional civil law concepts. This group showed us that the theoretical interpretation of criminal insanity was generally unison, while the individual differences between the regulations influence the successful application of the insanity plea before the courts. Common law, as shown in the paper, perceives insanity in a radically different 
way than civil law systems. In these countries, criminal insanity is a procedural institute and an official court defence, which in turn results in it being perceived very differently when compared to the substantive concept in civil law. Japanese and Chinese law served as examples of mixed legal systems with both civil and common law elements, but the very nature of criminal insanity in those countries is closer to the civil, rather than common law model. Finally, Iranian law was selected as an example of Sharia law, which, despite having the same theoretical basis, shows large differences in its religious perception of the criminal justice system.

The second part of the paper dealt with the practical application and means of establishing criminal insanity through the processes of expert evaluation, i.e., criminal (offender) profiling. By providing a summary description of these two techniques, the author presented and gave a critical evaluation of the two profiles of Anders Behring Breivik that had been presented to the Oslo court, and which were, interestingly enough, completely contrary to each other. One of the profiles suggested Breivik had paranoid schizophrenia, which would have made him criminally insane, while the subsequently made profile dismissed those conclusions and declared Breivik to have been sane, with a diagnosis of narcissistic personality disorder. A critical evaluation of both profiles was made, highlighting the weak points of the first profile and expressing support for the second profile. This section also superficially analysed the importance of psychological profiling in criminal proceedings and the process of establishing criminal insanity, thereby opening two interesting issues regarding the merits of profiling and the redefinition of criminal insanity in accordance with our insights in psychology and psychiatry. The most important conclusion of this section pertains to the importance of correct profiling/expert evaluation of the offender, given the fact that the implications of these procedures are practically essential for the criminal procedure. Though uncertainties and contradictions may arise during profiling, because of the complexities of the psychopathologies in question and the fact that the current definition of criminal insanity is outdated in regards to scientific findings regarding the human psyche, it is of vital importance that the procedure is executed in a detailed, comprehensive and precise fashion in order to precisely determine the perpetrator's state of mind and correctly apply penal regulations.

The third, final section of the paper was used to provide an applied summarization of the first two sections, in which the theoretical aspects from the first section were combined with the two possible outcomes presented in the second section. The basic inspiration for this section was the fact that Breivik would have had a different procedural treatment had he been declared criminally insane than had he been deemed sane. In line with that dichotomy, it was interesting to experiment with those possibilities in such a way that legal systems from the first part of the paper were tested in order to see the outcome of the proceedings against Breivik in both possible cases. The procedural outcome was, interestingly enough, the same in both cases - in case of being declared criminally insane, Breivik would have been committed to psychiatric care, which could, at least generally, last until his death, while in the case of him being declared sane, he would have been sentenced to either long-term (or lifetime) imprisonment or a harsher type of sanction. This aspect was used to illustrate the differences between the more liberal and more conservative penal systems through the prism of the strictness of their sanctions. On the other hand, the pro- 
cedural paths that led to these outcomes were very different, and, more than any other part of this paper, served to reflect the differences among the systems, which was, in turn, used to demonstrate how different systems function depending on their ideological perceptions of the functions of criminal proceedings, but also the larger legal systems these individual systems belong to.

Finally, this paper was focused on Anders Behring Breivik, as much as it was on universal issue of severe, violent crime, i.e., the variants and issues that modern criminal justice systems face while trying to solve them and balance the interests of the public, the individual and justice. The author hopes that he managed to clearly explain, argue for and provide proof for his proposals and conclusions. Access to most of the data was rather simple, with the exception of the precise data and interpretations of Sharia's practices, a consequence of the absence of (un)official translations and the closed nature of that system. However, bibliographic sources and international documents that deal with individual aspects of Iranian law were used for this context, which allowed for the collection and verification of information.

The author also hopes that this study will be of use to everyone interested in this case, but also in the issue of the psychology of violent crime within the legal system. The comparative approach to criminal insanity reveals not only interesting theoretical differences but also has numerous practical implications related to potential substantive and procedural reforms, as well as related to the protection of basic rights of the criminally insane, which are often disregarded in especially complex cases. This study also represents a suitable starting point for a debate on the compatibility of contemporary definitions of criminal insanity and modern scientific findings on the human mind, but also for a debate regarding the issue of severe personality disorders in the context of the criminal justice system.

\section{Epilogue}

In the end, this story deserves a short epilogue about the fate of Anders Behring Breivik, so that the story that inspired this paper can properly come to an end. Immediately after reporting to prison, Anders Behring Breivik was urgently isolated from all other prisoners, and only had contact with healthcare workers and prison personnel. He spends his time in solitary confinement, in deep isolation, and has limited access to the outside world, including the mail that he receives or sends.

His mother died from cancer in 2013; Breivik's request for release in order to attend the funeral was denied.

Despite not acknowledging the legitimacy of the Oslo court and not appealing his verdict, Breivik later sued the government over the poor prison conditions and violations of basic rights, claiming that the isolation he had been placed in was inhumane and that his rights were being violated by controlling the mail he was receiving and sending. After unsuccessfully fighting the government in front of national courts, Breivik appealed to the European Court of Human Rights (request no. 48852/17, [2018] ECHR 531), but also in vain. 
In 2017, he officially changed his name to Fjotolf Hansen, under which he is currently serving the prison sentence. Breivik (Hansen) is expected to serve out his sentence in 2033 when he is going to be 54 . Considering that he has shown no signs of rehabilitation while in prison, and would still be vital enough at that age to be considered dangerous, the author of this text expresses the hope and belief that the Norwegian justice system will make rightful and adequate use of the regulations governing the extension of preventive detention, and keep Breivik in prison even after the main sentence has been served, which seems to be the only right, just and fair decision that would bring a deserved end to this tragedy.

Provenance: Submitted. Based partly on the ideas from the master's thesis by Mislav Burazer „The Issue of Personality and Related Disorders in Criminal Law and Procedure", the sole author of this paper, at the University of Split, Faculty of Law, Split, Croatia.

Peer review: Externally peer reviewed.

Received: 27 November 2019 / Accepted: 18 June 2020 / Published online: 30 July 2020.

Funding: This research received no specific grant from any funding agency in public, commercial or not-for-profit sectors.

Authorship declaration: MB is the sole author of this study.

Competing interests: The author completed the ICMJE Unified Competing Interest form (available upon request from the corresponding author), and declares no conflicts of interest.

\section{ORCID}

Mislav Burazer (D) https://orcid.org/0000-0003-1101-3096

\section{References}

Abrahamian, E. (1999). Tortured Confessions: Prisons and Public Recantations in Modern Iran. Berkeley, CA: University of California Press.

Abrahamian, E. (2008). A History of Modern Iran. Cambridge: Cambridge University Press.

Act on the Protection of Persons with Mental Disorders (Croatian: Zakon o zaštiti osoba s duševnim smetnjama), NN 76/14 (2014). Retrieved from: https://www.zakon.hr/z/181/Zakon-o-zaštitiosoba-s-duševnim-smetnjama.

Act on the Provision and Implementation of Mental Health Care (Mental Health Act) (Lov om etablering og gjennomføring av psykisk helsevern [Psykisk helsevernloven]), LOV-1999-07-06-62 (1999). Retrieved from: https://lovdata.no/dokument/NL/lov/1999-07-02-62.

Akyol, M. (July 22, 2016). Who Was Behind the Coup Attempt in Turkey? The New York Times. Retrieved from https://www.nytimes.com/2016/07/22/opinion/who-was-behind-the-coupattempt-in-turkey.html.

All Human Rights for All in Iran (AHRAI) (2014). Iranian Penal Code: A report on the violations of human rights. [report presented at the 27th Session of the Human Rights Council of United Nations].

American Psychiatric Association (2013). Diagnostic and statistical manual for mental disorders (5th edition). Arlington, VA: American Psychiatric Publishing.

Amnesty International (2017). Blood-soaked Secrets: Why Iran's 1988 Prison Massacres Are Ongoing Crimes Against Humanity. London: Amnesty International, Ltd. 
Amnesty International (2018). Amnesty International Report 2017/18: The State of the World's Human Rights. London: Amnesty International, Ltd.

Boucht, J. (2015). Innføring i alminnelig strafferett. [PowerPoint presentation]. Retrieved from https:// www.uio.no/studier/emner/jus/jus/JUS4211/h16/undervisningsmateriale\%20i\%20strafferett/ innforing-i-alminnelig-strafferett-2.pdf.

Burazer, M. (2016). Problematika poremećaja ličnosti i povezanih poremećaja u kaznenom pravu i postupku. Split: University of Split, Faculty of Law.

Burazer, M. (2019). Kriminalno profiliranje. Croatian Annual of Criminal Sciences and Practice, 26(1), 91-118.

Burki, S.K. (2013). The Politics of State Intervention: Gender Politics in Pakistan, Afghanistan and Iran. Lanham, MD: Lexington Books.

Code of Public Health (French: Code de la santé publique), JORF n0237 (1953). Retrieved from: https:// www.legifrance.gouv.fr/affichCode.do?cidTexte=LEGITEXT000006072665.

Criminal Code of the Republic of Croatia (Croatian: Kazneni zakon Republike Hrvatske), NN 125/11 (2011). Retrieved from: http://www.mvep.hr/files/file/dokumenti/prevodenje/zakoni/kaznenizakon-nn-125-11-eng.pdf.

Criminal Code of the Russian Federation (Russian: Уголовный кодекс Российской Федерации Ugolovnyy kodeks Rossiyskoy Federatsii), N 63-F3/1996. (1996). Retrieved from: https://www. wipo.int/edocs/lexdocs/laws/en/ru/ru080en.pdf.

Criminal Law of the People's Republic of China (Chinese: 中华人民共和国刑法), 2nd Session of the Fifth National People's Congress, 1979 (1979). Retrieved from: https://www.fmprc.gov.cn/ce/ cgvienna/eng/dbtyw/jdwt/crimelaw/t209043.htm.

Criminal Procedure Law of the People’s Republic of China (Chinese: 中华人民共和国刑事诉讼法), 2nd Session of the Fifth National People’s Congress, 1979 (1979). Retrieved from: https://www.oecd. org/site/adboecdanti-corruptioninitiative/46814279.pdf.

Fox, R.G. (1983). Structure of the Criminal Prosecution and Trial Process in the People's Republic of China. Australian \& New Zealand Journal of Criminology, 16(3), 133-145.

Freckelton, I. (2007). Reform of Insanity Laws Needed in China: Lessons from the Qiu Xinghua Case. Psychiatry, Psychology and Law, 14(1), 1-4.

General Civil Penal Code (Norway: Almindelig borgerlig Straffelov), LOV-1902-05-22-10 (1902). Retrieved from: https://lovdata.no/dokument/NLO/lov/1902-05-22-10.

General Penal Code of Iceland (Almenn hegningarlög), Íslensk lög 143b/1940 (1940). Retrieved from: https://www.government.is/library/Files/General_Penal_Code_sept.-2015.pdf.

Göktürk, N., Özgenç, İ., Üzülmez, İ. (2012.). Ceza Hukukuna Gurış. Eskişehir: University of Anatolia.

Hallaq, W. (2009). Sharī’a: Theory, Practice, Transformations. Cambridge: Cambridge University Press.

Horvatić, Ž., Derenčinović D., Cvitanović, L. (2017). Kazneno pravo, Opći dio II. Zagreb: University of Zagreb, Faculty of Law.

Islamic Penal Code of Iran (Persian: نارىا ىمالسا تازاجم نوناق), Majlis, 2012. (2012). Retrieved from: https://www.refworld.org/docid/518a19404.html.

Jacobsen, C., Maier-Katkin, D. (2015). Breivik’s Sanity: Terrorism, Mass Murder, and the Insanity Defense. Human Rights Quarterly, 37(1), 137-152.

Johannessen, R. (April 16, 2012). Slik var Behring Breiviks bevegelser på Utøya. Aftenposten. Retrieved from https://www.aftenposten.no/norge/i/e8BwR/slik-var-behring-breiviks-bevegelser-paautoeya.

Kozarić-Kovačić, D., Grubišić-Ilić, M., Grozdanić, V. (2005). Forenzička psihijatrija. Zagreb: Medicinska naklada.

Krapac, D. (2015). Kazneno procesno pravo, Prva knjiga: Institucije. Zagreb: Narodne novine.

Kremer, J., Stigset, M., Treloar, S. (July 25, 2011). Norway Killing Suspect Ordered Into Isolation for Four Weeks. Bloomberg. Retrieved from https://www.bloomberg.com/news/articles/2011-07-24/ norway-killing-suspect-may-explain-motives.

Landsend, M., Kongsli Lundervold, L., Brynne, S., Thorenfeldt, G., Hattrem, E., Meland, A. (July 27, 2011). Skrøt av egen briljans, utseende, kjærester og penger. Dagbladet. Retrieved from https:// www.dagbladet.no/nyheter/skrot-av-egen-briljans-utseende-kjaerester-og-penger/63567745. 
Law on Fight Against Terrorism (Turkish: Terörle Mücadele Kanunu), Act no. 3713 (1991). Retrieved from: https://www.ilo.org/dyn/natlex/natlex4.detail?p_lang=en\&p_isn=22104\&p_ country=TUR\&p_count=801\&p_classification=01.04\&p_classcount=30.

Meldalen, S.G., Brustad, L., Kristiansen, A.A., Sandli, H., Espen F., Krokfjord, T.P. (April 2nd 2012). Breivik planla tagging som militær operasjon. Dagbladet. Retrieved from https://www. dagbladet.no/nyheter/breivik-planla-tagging-som-militaer-operasjon/63416139.

Mental Health Law of the People’s Republic of China (Chinese: 中华人民共和国精神卫生法), 29th Session of the Eleventh National People's Congress, 2012 (2012). Retrieved from: https://www. ncbi.nlm.nih.gov/pmc/articles/PMC4198897/.

Nakatani, Y., Kojimoto, M., Matsubara, S., Takayanagi, I. (2010.). New Legislation for Offenders with Mental Disorders in Japan. International Journal of Law and Psychiatry, 33, 7-12.

Novoselec, P., Bojanić, I. (2013). Opći dio kaznenog prava (4th edition). Zagreb: University of Zagreb, Faculty of Law.

Penal Code of Japan (Japanese: 刑法 Keihō), Act no. 45 (1907). Retrieved from: http://www. japaneselawtranslation.go.jp/law/detail/?id=1960\&re=02\&vm=04.

Penal Code of the French Republic (French: Code pénal), JORF n 169 (1992). Retrieved from: https:// www.legifrance.gouv.fr/affichCode.do?cidTexte=LEGITEXT000006070719.

Penal Code of the Kingdom of Norway (Norwegian: Lov om straff / Straffeloven), LOV-2005-20-28 (2005). Retrieved from: https://lovdata.no/dokument/NLE/lov/2005-05-20-28.

Penal Code of the Republic of Turkey (Turkish: Türk Ceza Kanunu), Act no. 5237 (2004). Retrieved from: https://www.legislationline.org/documents/section/criminal-codes/country/50/Turkey/ show.

Phillips, M.R., Chen, H., Diesfeld, K., Xin, B., Cheng, H.G., Mellsop, G., Liu, X. (2013) China’s New Mental Health Law: Reframing Involuntary Treatment. American Journal of Psychiatry, 170(6), 588-591.

Pradel, J. (2014). Droit pénal général (20th edition). Paris: Éditions Cujas.

Rognsvåg, S. (November 19, 2015). Breivik mener Jesus er «patetisk». Dagen. Retrieved from https:// www.dagen.no/Nyheter/hedning/Breivik-mener-Jesus-er-«patetisk»-272638.

Ronczkowski, M.R. (2017) Terrorism and Organized Hate Crime: Intelligence Gathering, Analysis and Investigations (4th edition). Boca Raton, FL: CRC Press.

Sakuta, T. (1991). Prison Psychiatry in Japan. Medicine and Law, 10, 275-284.

Suzuki, Y. (1973) Criminal Law Reform: Japan. The American Journal of Comparative Law, 21(2), 287303.

Tretvoll, H. (August 24, 2015). En modig dom. NRK. Retrieved from https://www.nrk.no/ytring/enmodig-dom-1.8293189.

UNHCR: Iran: Islamic Penal Code (November 22, 2019). Retrieved on November 23, 2019 from https:// www.refworld.org/docid/518a19404.html.

Walker, N. (1985). The Insanity Defense before 1800. The Annals of the American Academy of Political and Social Science, vol. 477, 25-30.

Wergeland, P., Zondag M., Jørstad R.H., Moland, A., Andersen I. (March 10, 2016). Norge har aldri evaluer Breiviks soningsregime. NRK. Retrieved from https://www.nrk.no/norge/norge-haraldri-evaluert-breiviks-soningsregime-1.12840018. 